\title{
Aldol Reactions between L-Erythrulose Derivatives and Chiral $\alpha$-Amino and $\alpha$-Fluoro Aldehydes: Competition between Felkin-Anh and Cornforth Transition States
}

\author{
Santiago Díaz-Oltra, Miguel Carda, Juan Murga, Eva Falomir, ${ }^{*}$ and J. Alberto Marco**@
}

\begin{abstract}
:
Both matched and mismatched diastereoselection have been observed in aldol reactions of a boron enolate of a protected l-erythrulose derivative with several chiral $\alpha$-fluoro and $\alpha$-Amino aldehydes. Strict adherence to the Felkin-Anh model for the respective transition structures does not account satisfactorily for all the observed results, as previously observed in the case of $\alpha$-oxygenatedaldehydes. In some cases, only the Cornforth model provides a good explanation. The factors that influence this dichotomy are discussed and a general mechanistic model is proposed for aldol reactions with a-heteroatom-substituted aldehydes. Additional support for the model was obtained from density functional calculations.
\end{abstract}

Keywords:

aldol reactions; boron enolates: density functional calculations; fluorine; transition states

\section{Introduction}

The aldol reaction is a powerful and general method for the stereocontrolled construction of carboncarbon bonds. ${ }^{1}$ Among the many enolate types investigated thus far, boron enolates have proven to be particularly versatile because of their good reactivity and excellent stereoselectivity. ${ }^{2}$ In recent years, we have investigated the outcome of aldol reactions of boron enolates generated from suitably protected Lerythrulose derivatives such as $\mathbf{1}$ and dicyclohexylboron chloride $\left(\mathrm{Chx}_{2} \mathrm{BCl}\right){ }^{3}$ With this class of ketone substrates, the latter reagent gives rise to the highly stereoselective formation of syn-aldols 2 via the (Z)enolate $\mathbf{1}_{\mathbf{B}}$ in reactions with achiral aldehydes RCHO (Scheme 1). ${ }^{4}$

Subsequent to these initial studies, we wondered whether or not the facial bias of chiral enolate $\mathbf{1}_{\mathbf{B}}$ would be strong enough to overcome the inherent facial preferences of the carbonyl group in $\alpha$-chiral aldehydes (double diastereoselection). ${ }^{[1 \mathrm{a}-\mathrm{e}]}$ Therefore, we investigated the aldol reactions of $\mathbf{1}_{\mathbf{B}}$ with a range of $\alpha$ chiral aldehydes in both antipodal forms. These aldehydes had either only carbon substituents ( $\alpha$-methyl aldehydes 3a and 3b) or else one oxygen atom ( $\alpha$-alkoxy aldehydes $\mathbf{4 a - c}$ ) bound to the $\alpha$-carbon atom. The results of these aldol reactions are summarized in Scheme $2 .^{5}$ In all successful reactions, the enolate $R e$ face attacks the aldehyde carbonyl $R e$ face.

\footnotetext{
* Dr. S. Díaz-Oltra, Prof. Dr. M. Carda, Dr. J. Murga, Dr. E. Falomir. Dep. de Q. Inorgánica y Orgánica, Universitat Jaume I. Avda. Sos Baynat s/n, 12071 Castellón (Spain)

@ Supporting Information for this article is available on the WWW under http://dx.doi.org/10.1002/chem.200800956. It contains experimental procedures for configurational assignments of the aldol adducts, the spectral data of compounds and correlation intermediates and copies of the NMR spectra.
} 
<smiles>CC1(C)OC[C@H](C(=O)C[SeH])O1</smiles>

1

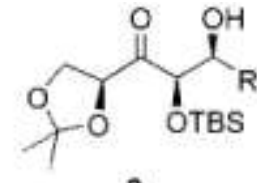

2

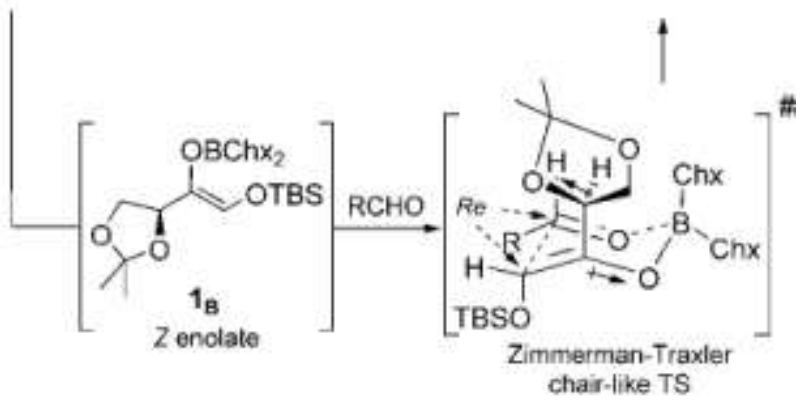

Scheme 1.Aldol additions of a boron enolate of ketone 1 to achiral alde-hydes ( TBS= tert-butyldimethylsilyl;Chx=cyclohexyl).

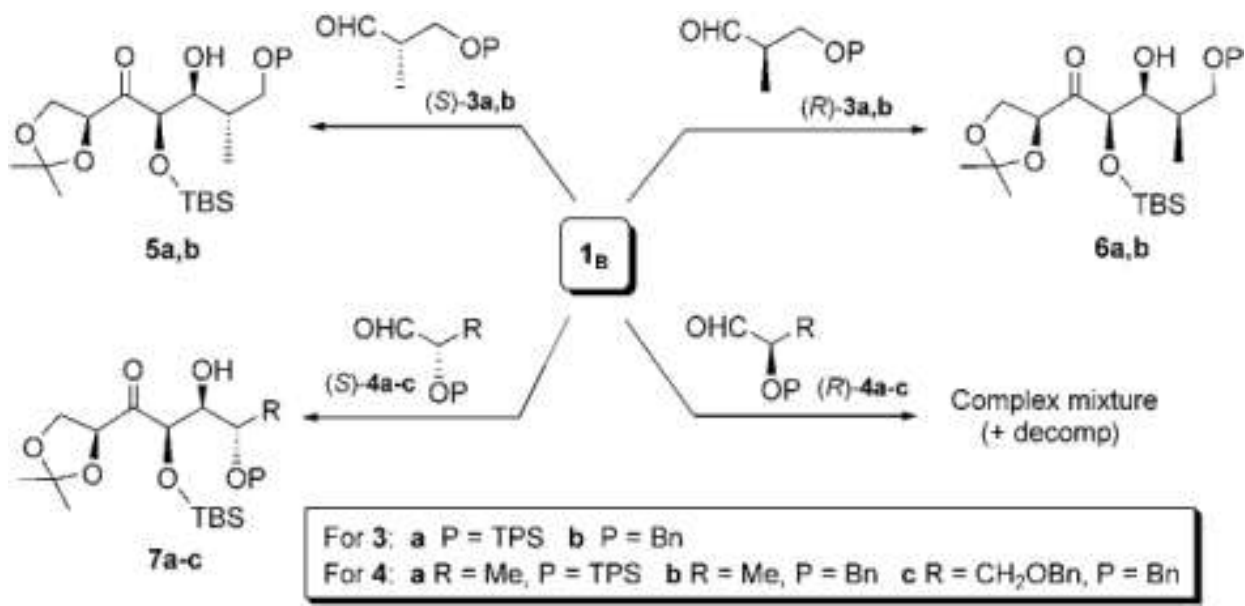

Scheme 2. Aldol additions of enolate $\mathbf{1}_{\mathbf{B}}$ to aldehydes $(R)$ - and $(S)-\mathbf{3}$, and $(R)$-and $(S)-\mathbf{4}(\mathrm{Bn}=$ benzyl; TPS= tert-butyldiphenylsilyl).

It is generally accepted that aldehydes react with boron enolates via cyclic, six-membered transition states (TS) of the Zimmerman-Traxler type (Scheme 1). ${ }^{[1-3,6,7]}$ Enolate $\mathbf{1}_{\mathbf{B}}$ displays a marked diastereofacial reference whereby exclusively its $R e$ face attacks the $R e$ face of the aldehyde carbonyl. This diastereofacial bias is attributed to the presence of a dipolar repulsion between the $\mathrm{C}_{-} \mathrm{O}_{\text {enolate }}$ and the $\mathrm{C} \alpha \_\mathrm{O}$ bonds, which compels them to orientate in an anticoplanar fashion (Scheme 1) ${ }^{[1 \mathrm{e}, 8]}$ As a result, the enolate $R e$ face is sterically more accessible than the $S i$ face, the latter now becoming blocked by the bulky dioxolane ring ${ }^{[3 c]}$ For the aldehyde, the $\mathrm{R}$ group preferentially adopts an equatorial orientation in the chair-like TS. This causes its carbonyl $R e$ face to be more reactive in these aldol reactions. On the basis of this reasoning, we proposed a mechanistic explanation for the difference in behavior between $\alpha$ methyl and $\alpha$-oxygenated aldehydes in our previous paper ${ }^{[5]}$ In addition to the aforementioned electronic and steric factors, a no-less-important element is the avoidance of steric repulsions of the so-called synpentane type between the OTBS group at the enolate $\mathrm{C}=\mathrm{C}$ bond and one substituent at the stereogenic $\alpha$ aldehyde carbon atom (Scheme 3). This feature, ${ }^{[1 \mathrm{a}, 5,9,10]}$ often present in aldol transition states involving (Z)-enolates, is believed to be a key stereocontrol element that determines aldehyde $\pi$-facial selectivities in many cases. For $\alpha$-methyl aldehydes $\mathbf{3 a}$ and $\mathbf{3 b}$, the concomitant influence of all these factors led to the proposal of transition state TS-1 for the aldol reactions of (S)-3, and TS-2 for those of (R)-3 (Scheme 3), in either case with avoidance of syn-pentane interactions. The former belongs to the Felkin-Anh (FA) type TS, ${ }^{11}$ even though a spatial approach at the Bürgi-Dunitz angle implies here that the nucleophile is closer to the methyl group than the hydrogen atom. ${ }^{[1,11,12]}$ The alternative TS-2 involves approach of a nucleophile to the carbonyl carbon atom along a trajectory that is not anticoplanar to the bulkiest substituent at the $\alpha$-carbon atom (the $\mathrm{CH}_{2} \mathrm{OP}$ moiety). This has been called a "non-Anh" TS. ${ }^{13}$ However, 
because both reactions take place easily under the usual conditions, the latter features seem to be minor factors here.
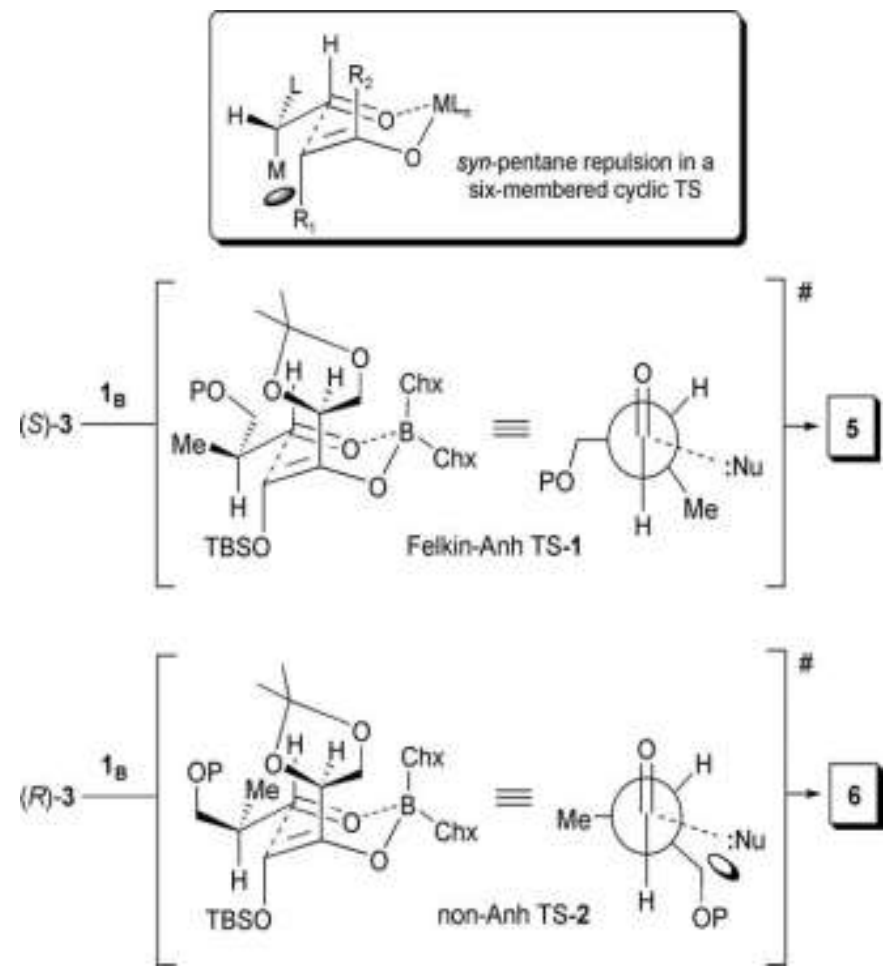

Scheme 3. Proposed transition states for the aldol additions of enolate $\mathbf{1}_{\mathbf{B}}$ to aldehydes $(R)$ - and $(S)$-3.

For $\alpha$-oxygenated aldehydes, however, a strict adherence to the Felkin-Anh model does not provide a satisfactory explanation of the observed results. ${ }^{[5]}$ We thus proposed that in such aldehydes, which contain an electronegative oxygen atom at the $\alpha$-carbon atom, dipolar repulsions in the transition states become meaningful. Consequently, Cornforth-like transition states were proposed, in which the aldehyde $\mathrm{C}=\mathrm{O}$ and $\mathrm{C}_{\alpha}-\mathrm{O}$ bonds are in an essential essentially anticoplanar orientation (Scheme 4). ${ }^{14}$ Indeed, such types of transition states had already been proposed for various carbonyl addition reactions, including aldol reactions with cyclic transition states. ${ }^{15},{ }^{16}$ The Cornforth TS-3, which does not show noticeable negative features of either steric or electronic nature, was therefore proposed for aldol reactions of aldehydes $(S)-\mathbf{4}$, in which aldols $\mathbf{7}$ are formed with good yield and excellent stereoselectivity. Aldehydes $(R)-\mathbf{4}$, however, must react through either the Felkin-Anh TS-4 of intrinsically higher energy than a Cornforth-type TS (higher dipolar repulsion) or through the Cornforth TS-5, which exhibits a strong synpentane steric interaction between the R and OTBS groups. Both transition states therefore are higher in energy than TS-3 and the reaction turns out to be slow and unselective. Besides, the alternative attack of the enolate on the aldehyde $S i$ face does not alleviate the situation, either, because other negative factors (see above) would then emerge. ${ }^{[5]}$ 

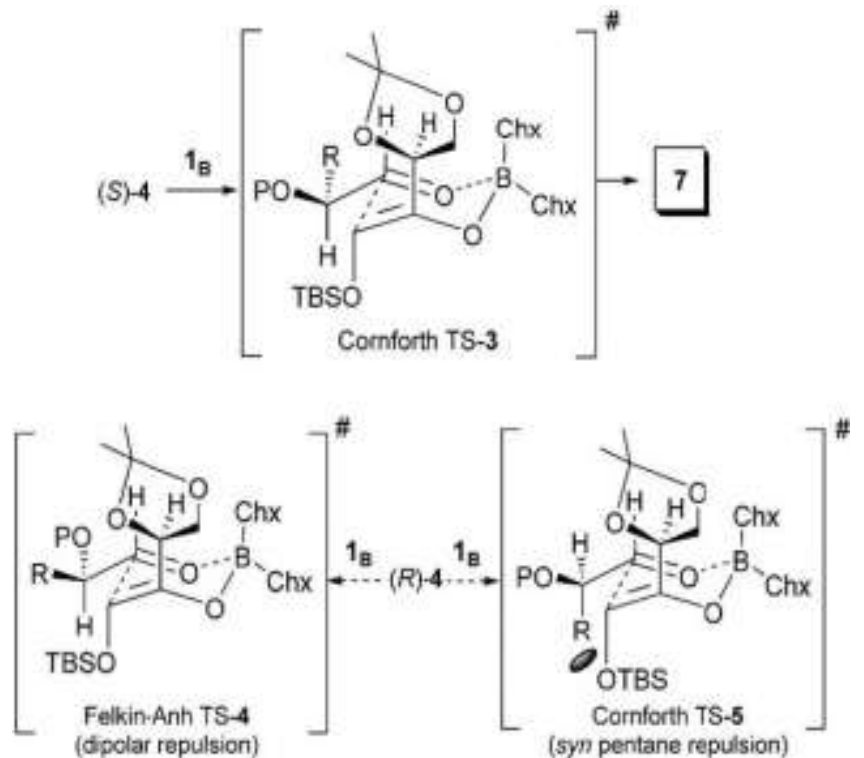

Scheme 4. Proposed transition states for the aldol additions of enolate $\mathbf{1}_{\mathbf{B}}$ to aldehydes $(R)$ - and $(S)-\mathbf{4}$

With the aim of investigating the relative importance of dipolar versus steric or stereoelectronic factors, we have now extended our study to the case of aldehydes containing other heteroatoms at the $\alpha$-carbon atom, more specifically $\alpha$-fluoro and $\alpha$-amino aldehydes. The former have the most electronegative atom and therefore the strongest dipolar repulsion factor in the transition states ${ }^{17}$. The latter have a much less electronegative atom, a feature which suggests that steric and dipolar repulsions may be of comparable magnitude. The results of the aldol reactions of the aforementioned aldehydes with boron enolate $\mathbf{1}_{\mathbf{B}}$ and the discussion of the observed results are one main subject of the present paper. In addition, we have performed the same type of study on two other enolizable compounds, both chiral and achiral, which we consider to be useful models to give a firmer basis to our mechanistic conclusions. ${ }^{18}$

\section{Results and Discussion}

Aldol reactions with chiral ketone 1: For the purposes described in the preceding section, the enantiomerically pure aldehydes 8a-b and 9a-c (Figure 1) were prepared in both antipodal forms according to described procedures. ${ }^{19}$

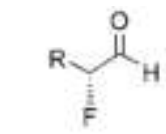

(R) $-8 \mathrm{a} \quad \mathrm{R}=\mathrm{CH}_{2} \mathrm{OBn}$

(R) $8 \mathrm{~b} \quad \mathrm{R}=\mathrm{CH}_{2} \mathrm{Ph}$

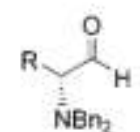

(R)-9a $\mathrm{R}=\mathrm{Me}$

(R) -9 b $\mathrm{R}=\mathrm{CH}_{2} \mathrm{Ph}$

(R)-9c $\mathrm{R}=\mathrm{CH}_{2}$ OTPS

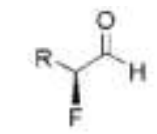

(S)-8a $\mathrm{R}=\mathrm{CH}_{2} \mathrm{OBn}$

(S) $8 \mathrm{~b} \quad \mathrm{R}=\mathrm{CH}_{2} \mathrm{Ph}$

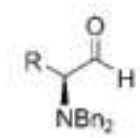

(S)-9a $R=M e$

(S)-9b $\mathrm{R}=\mathrm{CH}_{2} \mathrm{Ph}$

(S)-9c $\mathrm{R}=\mathrm{CH}_{2}$ OTPS

Figure 1. Chiral $\alpha$-fluoro and $\alpha$-amino aldehydes used in this study. 
The aldol additions were performed under the previously reported conditions (for experimental details, see the Supporting Information). ${ }^{3,5}$ We started with the aldol reactions of enolate $\mathbf{1}_{\mathbf{B}}$ with $\alpha$-fluoro aldehydes $(R)$ - and $(S)$-8. The results are shown in Scheme 5 and indicate that the $\alpha$-fluorinated aldehydes react in essentially the same way as those containing $\alpha$-oxygen atoms. The reactions with aldehydes $(S)-8$ were relatively rapid (total conversion in 5-6 h) and completely diastereoselective insofar as can be detected by NMR spectroscopic methods (d.r. >95:5). Aldols $\mathbf{1 0}$ were thus formed ${ }^{19}$ via enolate attack on the $R e$ aldehyde carbonyl face. In contrast, aldehydes $(R)-\mathbf{8}$ did not react with enolate $\mathbf{1}_{\mathbf{B}}$. Ketone $\mathbf{1}$ was recovered unchanged, together with decomposition products from the aldehyde.

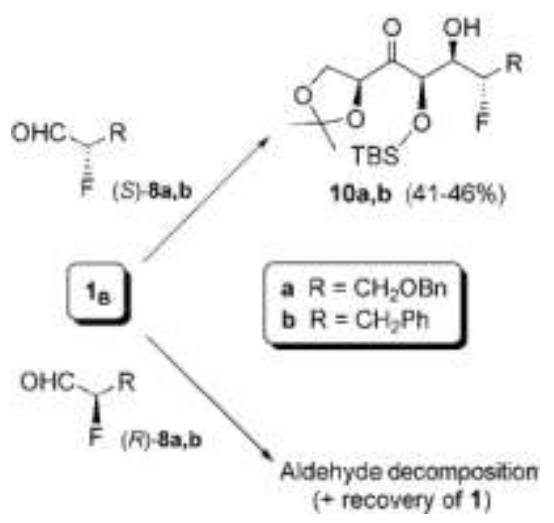

Scheme 5. Aldol additions of enolate $\mathbf{1}_{\mathbf{B}}$ to $\alpha$-fluoro aldehydes $(R)$-and $(S)$-8

The similarity of the results of the aldol reactions of 1 with $\alpha$-oxygenated and $\alpha$-fluorinated aldehydes suggests the same type of mechanistic explanation. Dipolar repulsions are presumably very strong here, due to the high electronegativity of fluorine. Thus, the successful reaction of aldehydes $(S)-\mathbf{8}$ to yield aldols 10 can be explained through assumption of the Cornforth transition state TS-6, with minimized dipolar repulsion and the absence of steric syn-pentane crowding (Scheme 6). In contrast, aldehydes $(R)-8$ are confronted with the choice between the Felkin-Anh TS-7, which shows noticeable dipolar repulsion, and the Cornforth TS-8, which shows a marked steric syn-pentane interaction.

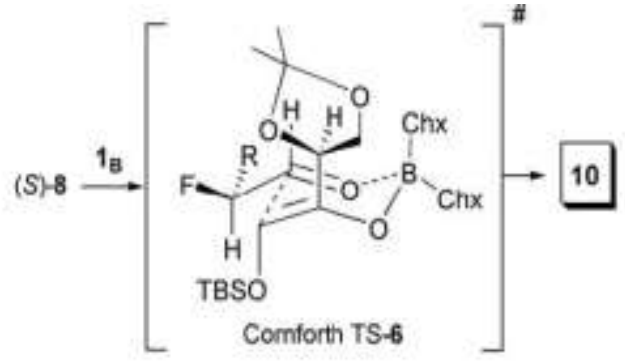

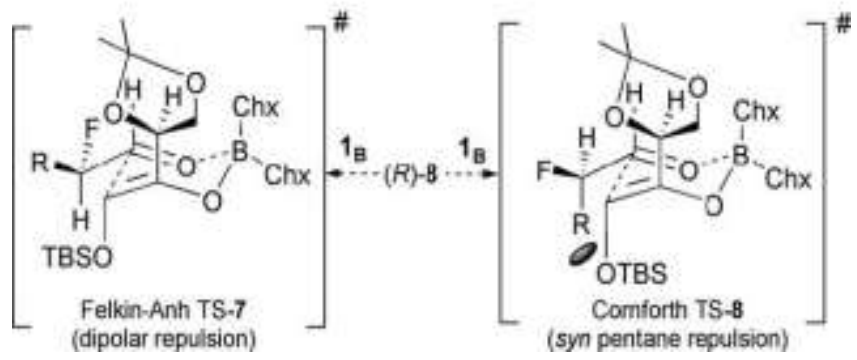

Scheme 6. Proposed transition states for aldol additions of enolate $\mathbf{1}_{\mathbf{B}}$ to $\alpha$-fluoro aldehydes $(R)$-and $(S)$-8. 
Both alternative transition states therefore show an increased energy content, which explains the failure of the corresponding aldol reactions. Furthermore, this indicates that the magnitude of the syn-pentane steric factor in the present case is comparable with, or possibly higher than, the dipolar repulsion of the $\mathrm{C}=\mathrm{O} / \mathrm{C}_{\alpha}-\mathrm{X}$ bonds, even in the case of the very electronegative fluorine atom.

The results of the aldol reactions of $\mathbf{1}$ with $\alpha$-amino aldehydes $\mathbf{9 a}-\mathbf{c}$ are shown in Scheme 7. As previously observed with $\alpha$-methyl aldehydes, ${ }^{5}$ both the $S$ and the $R$ enantiomers react with $\mathbf{1}_{\mathbf{B}}$ and provide aldols 11 and 12, respectively, with a good stereoselectivity (d.r. >95:5).

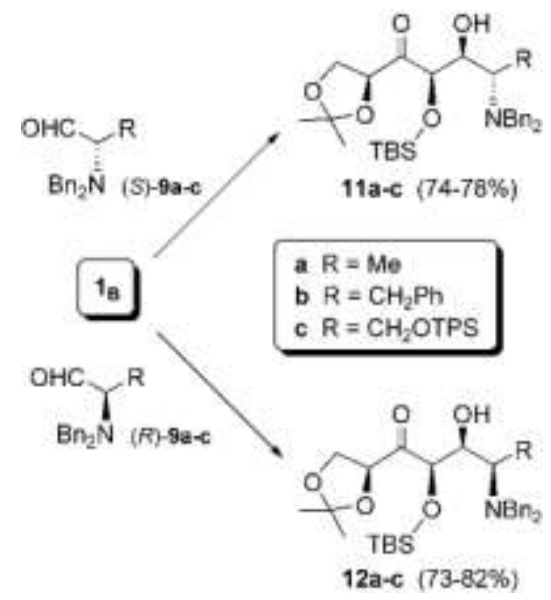

Scheme 7. Aldol additions of enolate $\mathbf{1}_{\mathbf{B}}$ to $\alpha$-amino aldehydes $(R)$ - and $(S)$-9.

These results contrast with those of the previously discussed $\alpha$-heteroatom-substituted aldehydes. Indeed, they indicate that dipolar repulsions are here of a much lesser magnitude. Due to the comparatively low electronegativity of the nitrogen atom, the dipolar repulsion of the $\mathrm{C}=\mathrm{O}$ and $\mathrm{C}-\mathrm{N}$ bonds is not very strong. Thus, steric syn-pentane interactions are in all likelihood the dominant factor of stereocontrol. Accordingly, TS-9 and TS-10, both devoid of such interactions (Scheme 8), are proposed to be reasonable transition structures for the reactions of aldehydes $(S)$ - and $(R)-\mathbf{9}$, respectively. Transition structure TS-9 belongs to the Cornforth type whereas TS-10 is clearly a Felkin-Anh TS, with attack of the enolate on the carbonyl carbon atom taking place in an almost antiperiplanar orientation to the $\mathrm{C}-\mathrm{N}$ bond, itself arranged in a perpendicular fashion to the carbonyl plane.
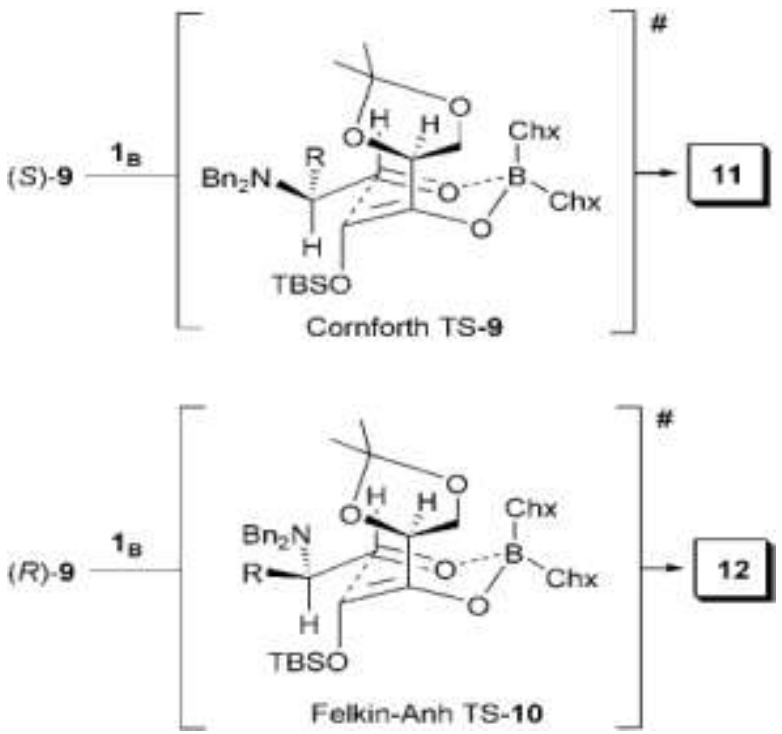

Scheme 8. Proposed transition states for aldol additions of enolate $\mathbf{1}_{\mathbf{B}}$ to $\alpha$-amino aldehydes $(R)$ - and $(S)-\mathbf{9}$. 
Aldol reactions with achiral ketone 13: The previous aldol reactions show the combined effects of the stereochemical biases of either chiral component (double diastereoselection). ${ }^{1 \mathrm{c}}$ To gain an insight into the intrinsic diastereofacial bias of the chiral aldehydes used in this study, we investigated their aldol reactions with achiral ketone 13, a dihydroxyacetone derivative structurally related to $\mathbf{1}$, which also forms a (Z)-enolate with $\mathrm{Chx}_{2} \mathrm{BCl}^{[3 \mathrm{~d}]}$ Scheme 9 shows the results of its reactions with aldehydes $\mathbf{3 a}, \mathbf{4 c}, \mathbf{8 b}$, and 9b (reactions were performed with either enantiomer but only the $R$ antipode is depicted in Scheme 9). For aldehydes containing a nitrogen atom or no heteroatoms in the $\alpha$ position, the reaction showed a moderate diastereoselectivity, with diastereomeric ratios being about 4-5:1 (the major syn aldol is that depicted in Scheme 9). The reaction also displayed a similar diastereoselectivity in the case of the $\alpha$ oxygenated aldehydes. However, it was very stereoselective for $\alpha$-fluorinated aldehydes, with only one aldol being detected (d.r. >95:5).

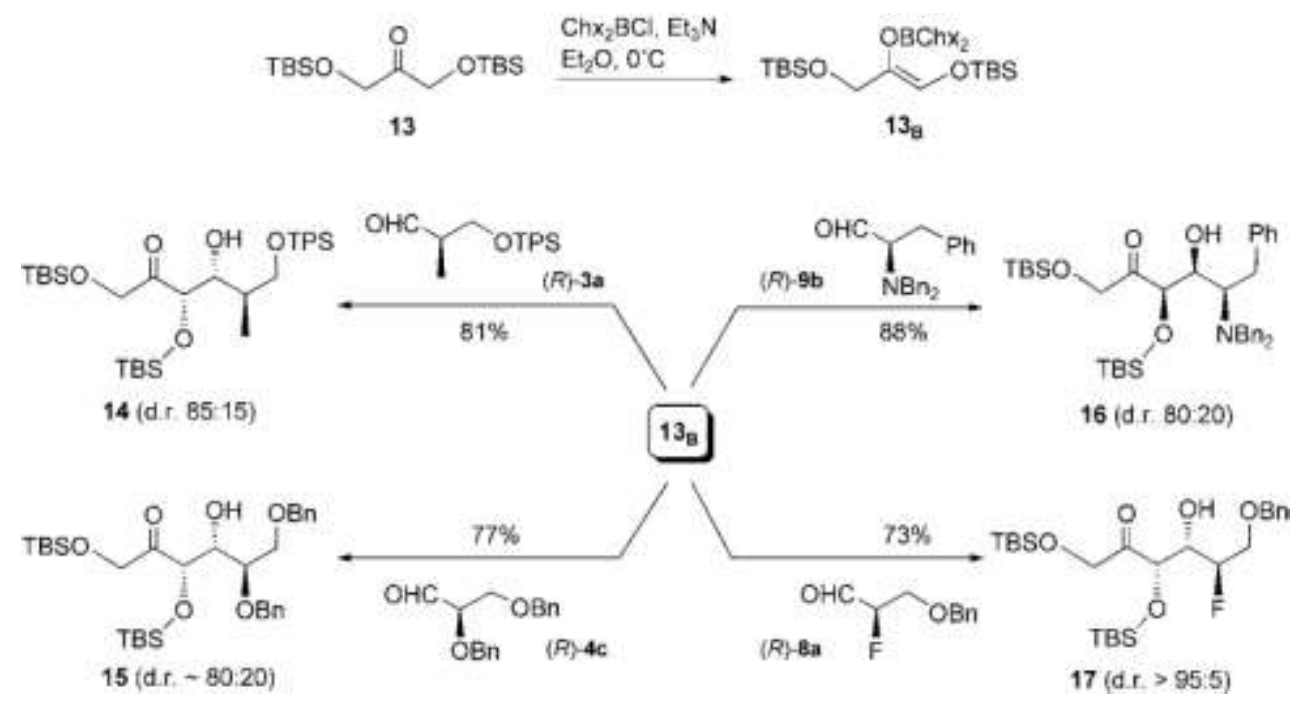

Scheme 9. Aldol additions of enolate $\mathbf{1 3}$ B to aldehydes $(R)-\mathbf{3 a},(R)-\mathbf{4 c},(R)-\mathbf{8 a}$ and $(R)-\mathbf{9 b}$ (major aldol depicted in each case).

These results can be explained within the same mechanistic frame detailed above, in which the main factor is again the avoidance of syn-pentane steric interactions in the transition states (Scheme 10). Accordingly, $(R)$-aldehydes without $\alpha$-heteroatoms react through the Felkin-Anh TS-11 (attack on the aldehyde $S i$ face) in preference to the non-Anh TS-12 (attack on the aldehyde $R e$ face). Polar effects are negligible here so that the sterically less congested TS-11 (attack anti to the bulky $\mathrm{CH}_{2} \mathrm{OP}$ ) takes over. This explains the formation of the observed major aldol $\mathbf{1 4}$ and the moderate diastereoselectivity (Scheme 9).

For aldehydes containing $\alpha$-heteroatoms the situation was found to be different. In the case of $(R)$ - $\alpha$ amino aldehydes, the choice is between the Felkin-Anh TS-13 (attack on the aldehyde Re face) and the Cornforth TS-14 (attack on the aldehyde $S i$ face), both of which are devoid of syn-pentane interactions (Scheme 10). In our mechanistic view, the major product 16 is that formed through the Felkin-Anh TS-13 because the electronegativity of the nitrogen atom is not very high. This reduces, therefore, the dipolar repulsion component and makes the Cornforth TS-14 comparatively less preferent. 
Aldol reactions with oxazolidinone 18: In relation to the latter issue and to complete our study, we wanted to compare the strength of the stereochemical bias of our ketone $\mathbf{1}$ with that of other wellestablished chiral auxiliaries of widespread use in aldol reactions such as, for example, Evans oxazolidinone 18. ${ }^{1 \mathrm{a}, \mathrm{i}, 2 \mathrm{a}}$ Thus, aldol reactions of a $(Z)$-boron enolate of this compound $\left(\mathbf{1 8}_{\mathbf{B}}\right)$ were allowed to react with $(R)$ - and $(S)$ - $\alpha$-oxygenatedand $\alpha$-fluorinated aldehydes of the type used above. ${ }^{20}{ }^{21}$ The results are shown in Scheme 12.
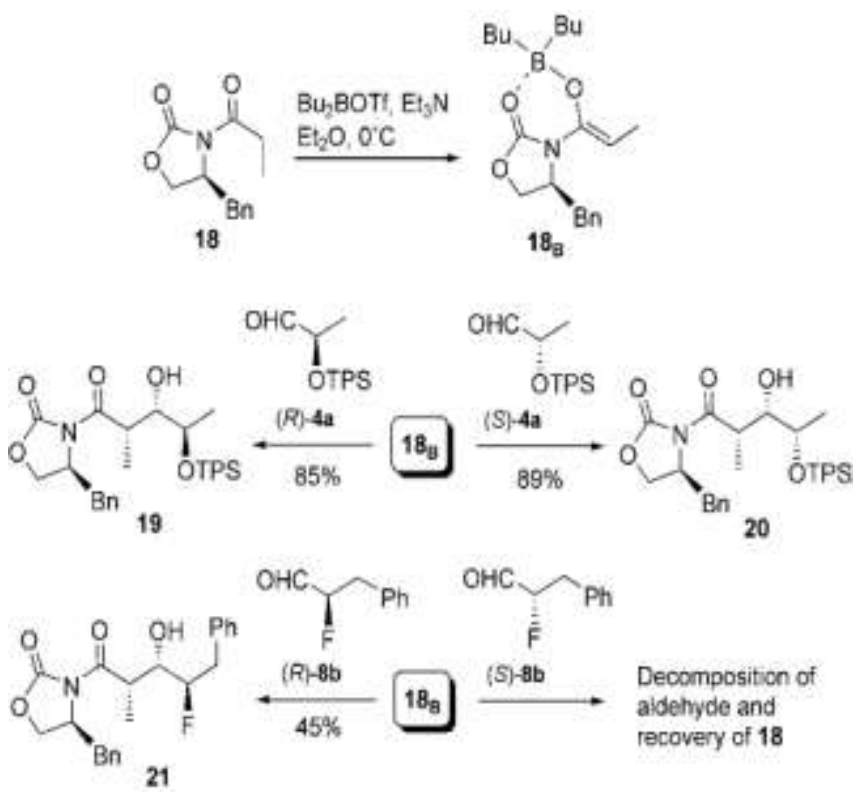

Scheme 12. Aldol additions of enolate $\mathbf{1 8}$ b to aldehydes $(R)-/(S)-\mathbf{4 a}$ and $(R)$ - and $(S)-\mathbf{8 b}$.

Following the mechanistic concepts disclosed above, these results may be explained as depicted in Scheme 13. It is known that enolate $\mathbf{1 8}_{\mathbf{B}}$ displays a strong bias towards attacking the $S i$ face of aldehyde carbonyl groups. ${ }^{1 \mathrm{a}, \mathrm{i}, 2 \mathrm{a}}$ Indeed, this is what happens with the $\alpha$-oxygenated aldehydes $(R)-$ and $(S)-\mathbf{4 a}$, as well as with the $\alpha$-fluorinated aldehyde $(R)-\mathbf{8 b}$. However, the aldol reaction with $(S)-\mathbf{8 b}$ turns out to be so slow that decomposition of the unstable aldehyde is the only observed result. Scheme 13 shows the proposed transition states for these reactions. Addition of $\mathbf{1 8}_{\mathbf{B}}$ to the $(R)$-aldehydes takes place via attack on the carbonyl Si face through the Cornforth TS-17, devoid of syn-pentane interactions. This type of steric crowding would be present, however, in the alternative Felkin-Anh TS-18, which becomes therefore much less favorable. In the case of the $(S)$-aldehydes, however, syn-pentane interaction is noticeable when the reaction goes through the Cornforth TS-20. Avoidance of this steric interaction by means of appropriate $\mathrm{C}-\mathrm{C}$ bond rotation leads to the Felkin-Anh TS-19. Obviously, this increases the energy of the TS because of the higher dipolar repulsion. Nevertheless, this seems to still be energetically feasible for the $\alpha$-oxygenatedaldehyde $(S)$-4a, which reacts to give aldol $\mathbf{2 0}$ as essentially a single stereoisomer. However, the $\alpha$-fluorinated aldehyde $(S)$-8b does not react at all, even after prolonged reaction times. The only reasonable explanation for this is that both alternative transition states (TS-19 and TS-20) have now undergone marked increases in their energy contents; the Felkin- Anh TS-19, apparently devoid of unfavorable steric features, is destabilized by the high dipolar repulsion between the $\mathrm{C}=\mathrm{O}$ and $\mathrm{C}-\mathrm{F}$ bonds, whereas the Cornforth TS-20 is destabilized by the syn-pentane interaction between the $\mathrm{Me}$ and $\mathrm{R}$ groups. 


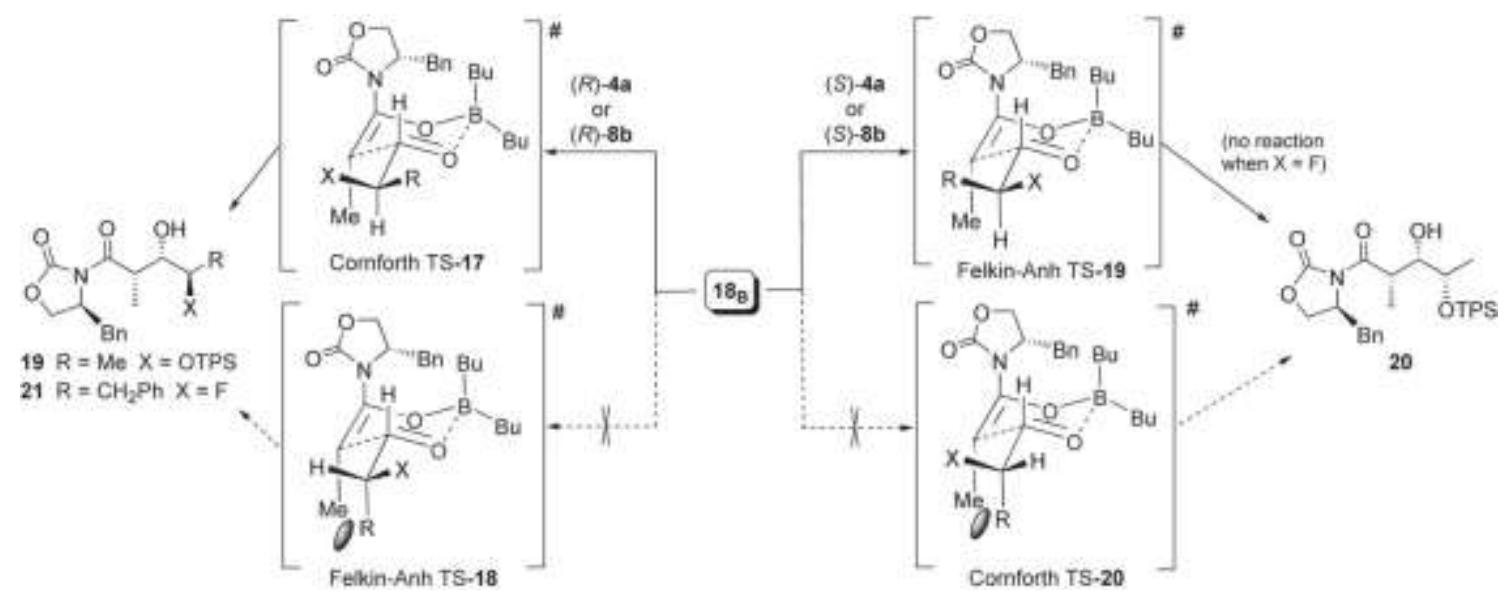

Scheme 13. Proposed transition states for aldol additions of enolate $\mathbf{1 8}_{\mathbf{B}}$ to aldehydes $(R)$ - and $(S)-\mathbf{4 a}$ and $(R)$ - and $(S)-\mathbf{8 b}$.

Quantum-mechanical calculations: In relation to the previously discussed experimental results, we wished to underscore our mechanistic proposals with the aid of quantummechanical calculations. For that purpose, and in view of the large number of atoms involved in the aldol reactions with our substrates, the simplified model molecules shown in Figure 2 were studied. Erythrulose enolate $\mathbf{1}_{\mathbf{B}}$ was replaced by the boron $(Z)$-enolate 22, which contains a methyl group instead of the bulky OTBS fragment. This change is justified by the fact that boron aldolization reactions carried out with an ethyl ketone very similar to $\mathbf{1}$ gave essentially the same results as $\mathbf{1}$ itself. ${ }^{4 a}$ Furthermore, the boron cyclohexyl groups have been replaced by methyl groups because although the size of the boron ligands is important for the stereochemical outcome of the enolization step, ${ }^{22}$ it does not exert a decisive influence on that of the aldol addition step. $^{3 \mathrm{c}}$ Finally, the $\alpha, \beta-O, O$-isopropylidene moiety was replaced by an $\alpha$-methoxy group. Compounds $(R)-\mathbf{2 3}$ and $(S)-\mathbf{2 3}$ were chosen as the model $\alpha$-chiral aldehydes. These aldehydes are the same as those used by Evans and co-workers in their theoretical calculations on boron aldol reactions with achiral enolates. ${ }^{7 \mathrm{~h}}$<smiles>C/C=C(/B(C)C)C(C)OC</smiles>

22<smiles>[X]C(C)C=O</smiles>

(R)-23a $X=\mathrm{NMe}_{2}$

(R) $-23 \mathrm{~b} X=\mathrm{OMe}$

(R) $-23 \mathrm{c} X=F$

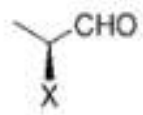

(S)-23a $X=\mathrm{NMe}_{2}$

(S) $-23 \mathrm{~b} \times \mathrm{X}=\mathrm{OMe}$

(S) $-23 \mathrm{c} X=\mathrm{F}$

Figure 2. Model molecules used in the quantum-mechanical calculations.

All calculations were carried out with the Gaussian 98 suite of programs. ${ }^{23}$ The B3LYP exchangecorrelation functional method ${ }^{24}$ with the $6-31 G^{* *}$ basis set $^{25}$ was used, as Evans and co-workers have shown that B3LYP is a reliable method for determining transition state structures in additions of boron enolates to aldehydes. ${ }^{7 \mathrm{~h}}$ The stationary points were characterized by frequency calculations to verify that minima and transition states have either zero or one imaginary frequency. Energy values were computed at $0{ }^{\circ} \mathrm{C}$, a temperature frequently used in these aldol reactions.

For calculations of energies, we have considered only those transition states with chair-like geometries with the R group of the aldehyde (RCHO) in an equatorial arrangement. The obtained energies have been found to be related to two specific dihedral angles $\varphi_{1}$ and $\varphi_{2}$, which are defined in Figure $3 .^{26}$ The FA model is based on transition states in which the principal stabilizing interaction is a hyperconjugative delocalization of the forming $\mathrm{C}-\mathrm{Nu}$ bond (HOMO) with the best vicinal acceptor, here the $\mathrm{C}_{\alpha}-\mathrm{X}$ bond (LUMO). This hyperconjugative interaction will be maximized when the forming $\mathrm{C}-\mathrm{Nu}$ bond and the $\mathrm{C}_{\alpha^{-}}$ $\mathrm{X}$ bond are antiperiplanar $\left(\varphi_{1}=1808\right)$. Because the Bürgi-Dunitz angle ${ }^{12}$ has to be taken into account, $\varphi_{1}$ should differ from the ideal angle of $180^{\circ}$ by no more than $10-20^{\circ}$ (i.e. $\pm 160-170^{\circ}$ ). Accordingly, $\varphi_{2}$ should not be far away from $\pm 90^{\circ}$. I n contrast, Cornforth transition states involve minimization of the 
dipolar repulsion between the $\mathrm{C}=\mathrm{O}$ and $\mathrm{C}_{\alpha}-\mathrm{X}$ bond. Consequently, $\varphi_{1}$ should be less than $\pm 90^{\circ}$ and $\varphi_{2}$ should differ from $180^{\circ}$ by no more than $10-20^{\circ}$.

Figure 3. Definition of $\varphi_{1}$ and $\varphi_{2}$ dihedral angles. $\varphi_{1}=\mathrm{C}_{1}-\mathrm{C}_{2}-\mathrm{C}_{3}-\mathrm{X}$. R, R' $=\mathrm{H}, \mathrm{Me}$.
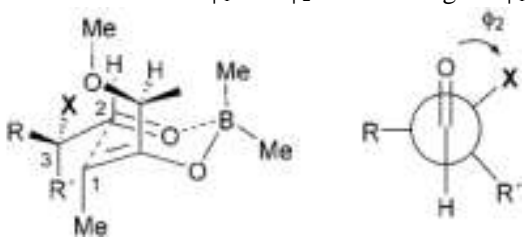

The Cartesian coordinates for all atoms in the different transition states are given in the Supporting Information. Table 1 shows some relevant geometrical features of these transition states. The extent of $\mathrm{C}-\mathrm{C}$ bond formation in transition states can be generally assessed by determining the distance between the reacting carbon atoms of the aldehyde and the enol borane. In the cases under study here, the lengths of the forming $\mathrm{C}-\mathrm{C}$ bonds are mainly in the range of $2.25-2.50 \AA$. There are three notable exceptions in the case of fluorinated aldehydes, in which these bonds are distinctly longer $(>2.60 \AA)$, which indicates earlier transition states (see below). ${ }^{27}$

\begin{tabular}{lccc} 
Transition structure $^{[\text {|a }}$ & $\varphi_{1}[8]$ & $\varphi_{2}[8]$ & $\mathrm{C}_{1} \mathrm{C}_{2}(\AA)$ \\
\hline TS-1A (C) & 48.4 & 154.8 & 2.43 \\
TS-1B (F) & 139.7 & -110.3 & 2.27 \\
& & & \\
TS-2A (C) & 45.7 & 155.1 & 2.33 \\
TS-2B (F) & 174.9 & -77.1 & 2.27 \\
& & & \\
TS-3A (C) & 49.9 & 155.3 & 2.43 \\
TS-3B (F) & 149.7 & -101.4 & 2.37 \\
TS-3C (C) & -57.9 & -164.9 & 2.40 \\
TS-3D (F) & -175.0 & 78.1 & 2.35 \\
& & & \\
TS-4A (C) & 37.3 & 147.1 & 2.34 \\
TS-4B (F) & 173.9 & -79.0 & 2.37 \\
TS-4C (C) & -68.2 & -173.4 & 2.40 \\
TS-4D (F) & -158.2 & 99.1 & 2.50 \\
& & & \\
TS-5A (C) & 63.6 & 165.1 & 2.84 \\
TS-5B (F) & 139.2 & -113.9 & 2.39 \\
& & & \\
TS-6A (C) & 68.1 & 170.2 & 2.64 \\
TS-6B (F) & 167.9 & -91.0 & 2.74
\end{tabular}

[a] Cornforth-type transition states are labeled with $\mathrm{C}$, whereas those of the Felkin-Anh type are labeled with F. For absolute energy contents of all transition states, see Supporting Information. Energy differences between comparable transition states are given in kcal mol in Figures 4-9.

Table 1. Calculated dihedral angles $\varphi_{1}$ and $\varphi_{2}$, and lengths of the forming C-C bonds of the transition states of all aldol reactions with the model molecules from Figure 2. 
Transition-state structures for addition of 22 to $\alpha$-amino aldehydes $(R)$ - and $(S)-23$ a: As mentioned above, the addition of erythrulose boron enolate $\mathbf{1}_{\mathbf{B}}$ to $\alpha$-amino aldehydes $(R)$ - and $(S)-\mathbf{9}$ exhibits good stereocontrol and only yields aldols formed by the attack of the enolate to the $R e$ face of the aldehyde carbonyl (Scheme 7). As for the model reactions, the calculated transition states for the addition of 22 to the $R e$ face of aldehydes $(S)-23 \mathbf{a}$ and $(R)-23 \mathbf{a}$ are shown in Figure 4 and Figure 5, respectively (in this and the following figures, the lowest-lying TS is assigned the relative energy $\left.0 \mathrm{kcal} \mathrm{mol}^{-1}\right)$. For the addition of 22 to $(S)$-23a the lowest-lying TS is the Cornforth-type TS-1A, in agreement with our experimental observations and qualitative mechanistic proposals (Scheme 7 and Scheme 8). The Felkin-Anh (FA) TS1B is here approximately $0.4 \mathrm{kcal}$ mol-1 higher in energy (Figure 4). The Cornforth TS-1A contains an arrangement of the $\mathrm{C}=\mathrm{O}$ and $\mathrm{C}-\mathrm{N}$ bonds (dihedral angle $\varphi_{2}=154.8^{\circ}$ ) which, although not fully antiparallel, reduces the dipolar repulsion in a marked proportion. However, the calculated $\varphi_{1}$ angle in the FA TS-1B is $139.7^{\circ}$, much lower than anticipated (see comments above). This deviation is due to the existence of a syn-pentane repulsion between the enolate olefinic methyl and aldehyde $\alpha$-methyl group (Figures 3 and 4). Rotation around the $C_{2}-C_{3}$ bond alleviates in part this steric interaction and causes at the same time a reduction of $\varphi_{1}$.

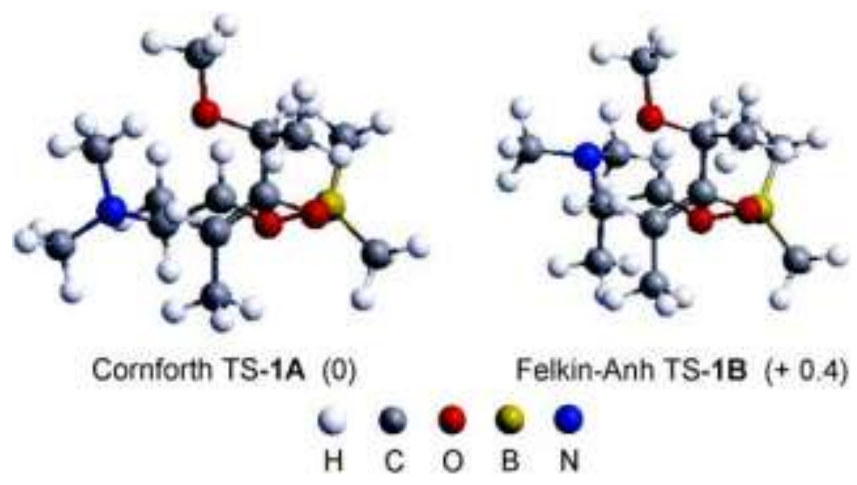

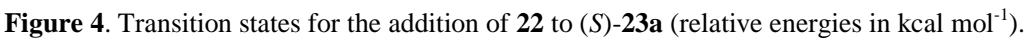

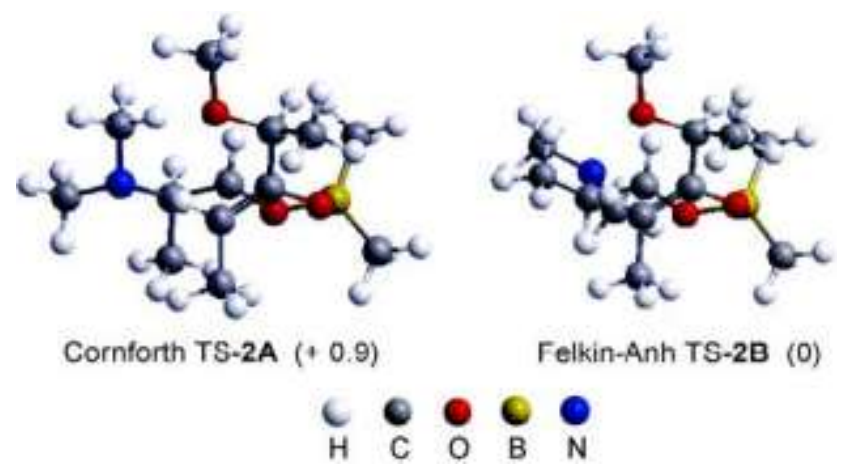

Figure 5. Transition states for the addition of 22 to $(R)-23 a$ (relative energies in $\mathrm{kcal} \mathrm{mol}^{-1}$ ).

The degree of involvement of the $\mathrm{C}-\mathrm{N}$ bond in the $\mathrm{Nu} \rightarrow \mathrm{O}^{*}{ }_{\mathrm{C}-\mathrm{N}}$ hyperconjugative interaction, which is believed to stabilize the FA TS-1B, can be estimated by comparing the C-N bond lengths in the TS and in the reactant aldehyde. As a matter of fact, the C-N bond in TS-1B has a calculated length of $1.474 \AA$ whereas in the reactant aldehyde $(S)$-23a this distance lies in the range between $1.468 \AA\left(\varphi_{2}=180^{\circ}\right.$, Cornforth-type conformation) and $1.476 \AA\left(\varphi_{2}=90^{\circ}\right.$, Felkin-Anh-type conformation). This close similarity strongly suggests that a Nu $\rightarrow \mathrm{O}^{*}{ }_{\mathrm{C}-\mathrm{N}}$ hyperconjugative interaction is almost absent in TS-1B, this being likely related to the rather low value of $\varphi_{1}$ (see above). Thus, this paradigmatic, energetically favourable feature of all FA transition states is absent here. All these features explain why the Cornforth TS-1A is the most favourable TS in the addition of 22 to $\alpha$-amino aldehyde $(S)$-23a. 
In the case of the addition of $\mathbf{2 2}$ to $(R)-\mathbf{2 3}$ a, the FA TS-2B is now the lowest lying one, with the Cornforth TS-2A being higher in energy by approximately $+0.9 \mathrm{kcal} \mathrm{mol}^{-1}$. Again, this is in line with our experimental observations and qualitative mechanistic proposals (Scheme 7 and Scheme 8). It is now worth noting that TS-2B has a $\varphi_{1}$ angle of $\approx 175^{\circ}$, a value much more similar to that expected for a FA transition structure. However, the C-N bond length (1.481 $\AA$ ) is only slightly higher than the length of the $\mathrm{C}-\mathrm{N}$ bond in the reactant aldehyde (range of values between 1.468 and $1.476 \AA$ ), a circumstance which, once again, does not suggest a sizeable $\mathrm{Nu} \rightarrow \mathrm{O}^{*}{ }_{\mathrm{C}-\mathrm{N}}$ hyperconjugative interaction in the TS. As regards the Cornforth TS-2A, it has a dihedral angle $\varphi_{2}=155.1^{\circ}$, a value similar to that calculated for TS-1A.

However, TS-2A exhibits a Me-Me syn-pentane repulsion of the aforementioned type that destabilizes it in relation to TS-2B.

The conclusion to be drawn from these calculations is essentially the same we had qualitatively derived from the experimental results with enolate $\mathbf{1}_{\mathbf{B}}$ (Scheme 7). The electronegativity of the nitrogen atom is not high enough to enforce an antiperiplanar arrangement of the aldehyde $\mathrm{C}=\mathrm{O}$ and $\mathrm{C}-\mathrm{N}$ bonds in the transition states of the aldol reactions. In fact, Evans and co-workers predicted by means of theoretical calculations that the ground-state conformation of $\alpha$-amino aldehydes shows a $\mathrm{C}=\mathrm{O} \cdots \mathrm{C}$-N dihedral angle ( $\varphi_{2}$ in the present paper) of nearly $150^{\circ}$, a value very similar to that found for the Cornforth TS-1A. However, the ener getic cost necessary for bringing it to about $90^{\circ}$ is not too high $\left(<2 \mathrm{kcal} \mathrm{mol}^{-1}\right){ }^{7 \mathrm{~h}} \mathrm{This}^{\mathrm{T}}$ means that either Cornforth or FA transition states may be available with similar ease in nucleophilic additions to $\alpha$-amino aldehydes.

Transition-state structures for addition of 22 to $\alpha$-oxygenated aldehydes $(R)$ - and $(S)-23 b$ : The addition of erythrulose enolate $\mathbf{1}_{\mathbf{B}}$ to $\alpha$-oxygenated aldehydes was found to exhibit a high degree of stereocontrol in the reaction with $(S)$ - $\alpha$-alkoxy aldehydes (Scheme 2). In contrast, the reaction with $(R)$ $\alpha$-alkoxy aldehydes provides a mixture of aldols, together with decomposition products. These results suggest that, in contrast to the other aldehyde types, the attack of the erythrulose enolate may take place here competitively on either face of the aldehyde carbonyl group. Therefore, we studied here the transition states, which result from the attack of the enolate on either the Re or the $S i$ face of the aldehydes.

Figure 6 shows the transition states for additions of $\mathbf{2 2}$ to the $R e$ and the $S i$ face of aldehyde $(S)$-23b. From the transition states associated with attack on the $R e$ face, the Cornforth TS-3A is the most favorable TS here, with the FA TS-3B being $1.1 \mathrm{kcal}$ mol-1 higher in energy. As before, this agreed well with our experimental observations and qualitative mechanistic proposals (Scheme 2 and Scheme 4). Additions to the $\mathrm{Si}$ face must go through markedly higher energy barriers. Indeed, the Cornforth TS-3C and the FA TS-3D are 2.6 and $1.3 \mathrm{kcal} \mathrm{mol}^{-1}$, respectively, higher in energy than TS-3A.

TSs of attacks on the aldehyde Re face

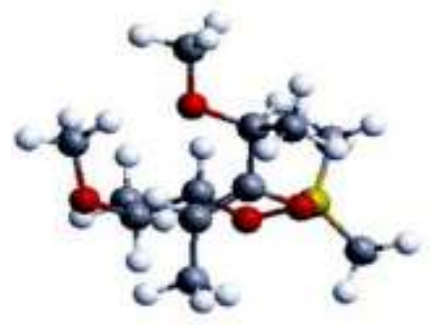

Cornforth TS-3A (0)

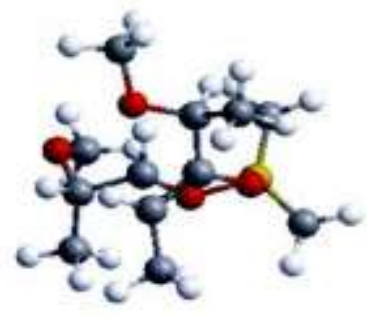

Felkin-Anh TS-3A $(+1.1)$

TSs of attacks on the aldehyde Si face

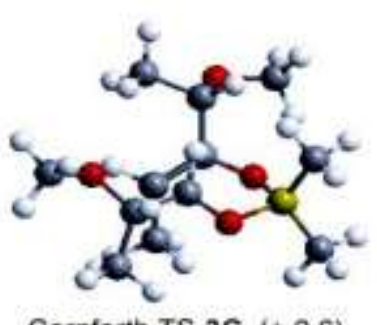

Cornforth TS-3C $(+2.6)$

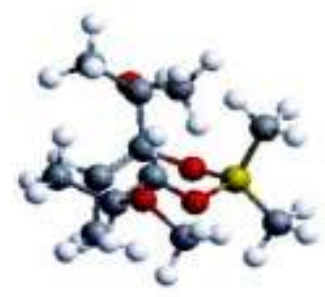

Felkin-Anh TS-3D $(+1.3)$

Figure 6. Transition states for the addition of 22 to $(S)$ 23b (relative energies in $\mathrm{kcal} \mathrm{mol}^{-1}$ ). 
From all four transition states, TS-3A shows the longest length for the forming C-C bond $(2.43 \AA)$ and is therefore the earliest one. In addition, it does not show any syn-pentane repulsion. However, $\varphi_{2}$ is $155.3^{\circ}$, a value very similar to that predicted for the Cornforth TS-1A with an $\alpha$-amino aldehyde (Table 1). This somewhat low value is perhaps unexpected for an $\alpha$-oxygenated aldehyde, which contains the more electronegative oxygen atom. In fact, the aforementioned calculations by Evans and co-workers ${ }^{7 \mathrm{~h}}$ predict a value $\varphi_{2}$ of approximately $180^{\circ}$ for $\alpha$-alkoxy aldehydes in the ground-state conformation ${ }^{28}$. Moreover, and in contrast with $\alpha$-amino aldehydes, the energetic cost necessary for bringing it to about $90^{\circ}$ is high $\left(>3 \mathrm{kcal} \mathrm{mol}^{-1}\right) .{ }^{7 \mathrm{~h}}$ However, rotation to an angle $\varphi_{2} \approx 155^{\circ}$ is not so costly $\left(\approx 0.5 \mathrm{kcal} \mathrm{mol}^{-1}\right)$ and may be easily achieved. The discrepancy between the anticipated antiperiplanar and the calculated arrangement may possibly be due to a steric repulsion between the aldehyde $O$-methyl group and the atoms at the stereogenic carbon center of the enolate, an interaction alleviated in part through $\mathrm{C}_{2}-\mathrm{C}_{3}$ bond rotation. As regards the FA TS-3B, the $\varphi_{1}$ angle is $149.7^{\circ}$, this somewhat low value being related to the presence of a Me-Me syn-pentane interaction, which is the main factor responsible for its increased energy content in comparison with TS-3A.

Quantum-mechanical calculations for the additions of $\mathbf{2 2}$ to the $R e$ and $S i$ faces of aldehyde $(R)$-23b (Figure 7) show that the FA TS-4B, associated with attack on the aldehyde Re face, has now the lowest energy content. The secondlowest energy content TS is the Cornforth TS-4C, corresponding to attack on the aldehyde $\mathrm{Si}$ face, which is relatively destabilized by $2.3 \mathrm{kcal} \mathrm{mol}^{-1}$. Still higher by $2.6 \mathrm{kcal}$ mol-1 is TS-4A (attack on the aldehyde $R e$ face). Finally, the FA TS-4D is the TS with the highest energy content $\left(+4.3 \mathrm{kcal} \mathrm{mol}^{-1}\right)$. As a matter of fact, TS-4B shows no unfavorable interactions of either electronic or steric kind. In contrast, TS-4A is destabilized by a syn-pentane interaction, and perhaps also by a steric repulsion between the aldehyde $O$-methyl group and the atoms at the stereogenic carbon atom of the enolate. The latter feature is suggested by the low value of the dihedral $\varphi_{2}$ angle $\mathrm{C}=\mathrm{O} \cdots \mathrm{C}-\mathrm{O}\left(147.1^{\circ}\right)$.

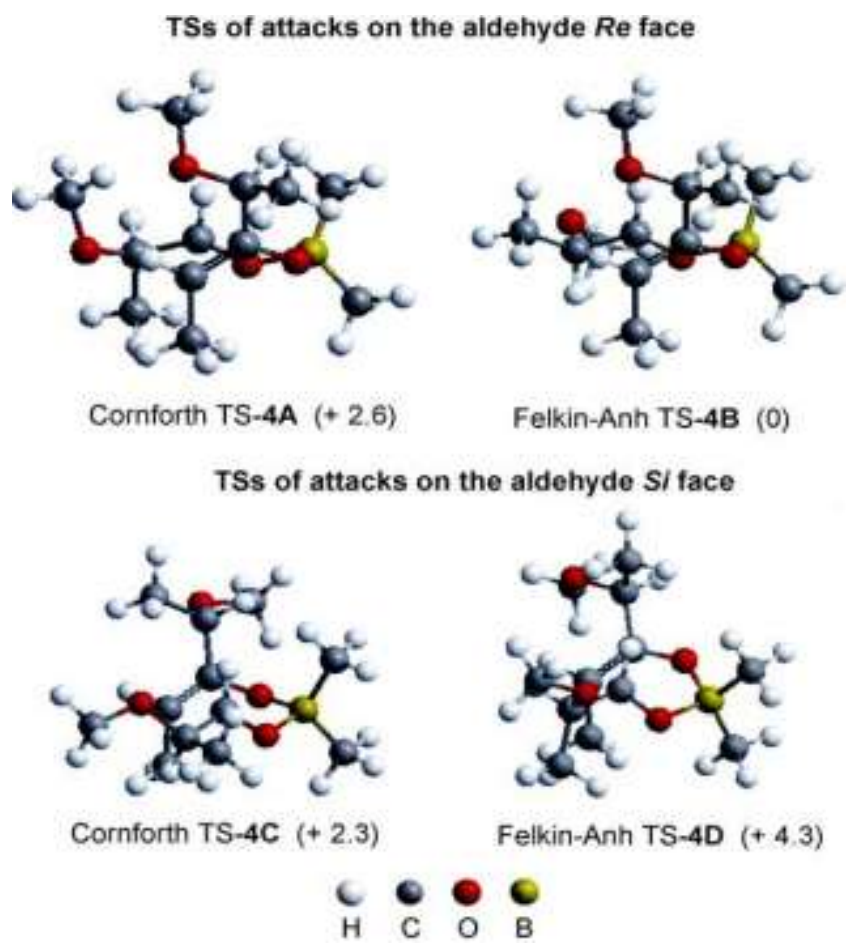

Figure 7. Transition states for the addition of $\mathbf{2 2}$ to $(R)$-23b (relative energies in $\mathrm{kcal} \mathrm{mol}^{-1}$ ).

The aforementioned calculations would lead to the prediction that $(R)$ - $\alpha$-alkoxy aldehydes react through a Felkin-Anh TS to yield mainly one diastereoisomer, different from that obtained with the $S$ aldehydes. Indeed, this happens with Evans chiral enolate $\mathbf{1 8}_{\mathbf{B}}$ (Scheme 12) but not when enolate $\mathbf{1}_{\mathbf{B}}$ is used (Scheme 2 ), as we only observed a slow and non-selective reaction. This result would suggest the existence of 
several competitive transition states (Scheme 4). However, whether the discrepancy results from the inadequacy of our model reaction or from the calculation level used here is not clear. ${ }^{29}$

Transition-state structures for addition of 22 to $\boldsymbol{\alpha}$-fluoro aldehydes $(\boldsymbol{R})$ - and $(\boldsymbol{S})-\mathbf{2 3}$ c: The lowest energy TS in the addition of $\mathbf{2 2}$ to aldehyde (S)-23c is the Cornforth TS-5A (Figure 8). Here, the dihedral $\mathrm{C}=\mathrm{O} \cdots \mathrm{C}-\mathrm{F}$ angle $\varphi_{2}=165.1^{\circ}$, a value very close to that calculated by Evans and co-workers $\left(166^{\circ}\right)$ for the reaction of $23 \mathbf{c}$ with a simple achiral enolborane. This indicates that the dipolar repulsion component is markedly reduced in this TS. This is a particularly relevant feature because the same group has shown that there is a high energetic cost (ca. $3.5 \mathrm{kcal} \mathrm{mol}^{-1}$ ) for bringing the $\mathrm{C}=\mathrm{O} \cdots \mathrm{C}-\mathrm{F}$ dihedral angle in 2fluoropropanal from its groundstate value of nearly $180^{\circ}$ to about $90^{\circ}$. ${ }^{7 \mathrm{~h}}$ In the case of the aforementioned aldol reaction, this means that the stereoelectronic advantage associated with FA transition states (C-F perpendicular to $\mathrm{C}=\mathrm{O}$ ) is not able to compensate the energetic penalty of the necessary conformational change. It is also worth mentioning that the length of the forming C-C bond in TS-5A (2.84 $\AA$ ) is markedly higher than in all other transition states, a feature which indicates that this TS is very early. In all likelihood, this is related to the high electrophilicity of the carbonyl group in $\alpha$-fluoro aldehydes, due in turn to the high electronegativity of the fluorine atom. In fact, an inspection of the bond angles around the boron atom (see Supporting Information) reveals a distinct pyramidalization of this atom in the TS. In addition to the aforementioned features, TS-5A does not exhibit unfavorable syn-pentane repulsions and is thus by far the preferred TS. This is in complete agreement with our experimental observations and qualitative mechanistic proposals (Scheme 5 and Scheme 6).

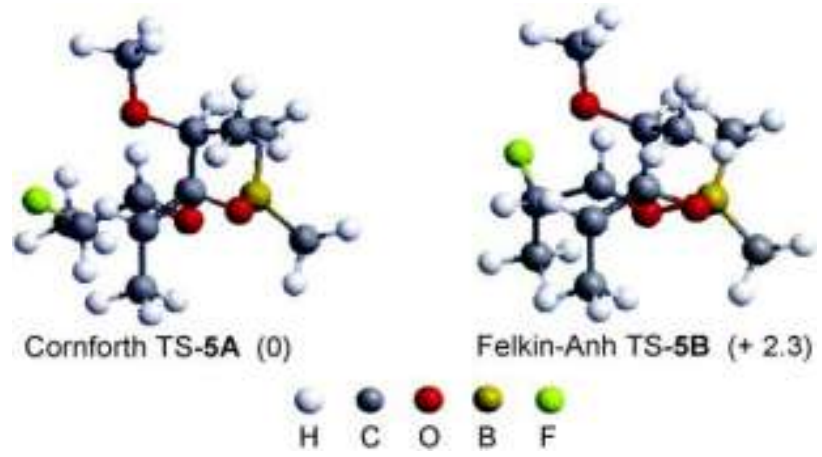

Figure 8. Transition states for the addition of 22 to $(S)$-23c (relative energies in $\mathrm{kcal} \mathrm{mol}^{-1}$ ).

Aside from the unfavorable dipolar repulsion factor discussed above, the FA TS-5B shows in addition a Me-Me syn-pentane interaction. This explains why this TS turns out to be higher in energy than TS-5A by the appreciable amount of $2.3 \mathrm{kcal} \mathrm{mol}^{-1}$ (Figure 8 ).

In contrast to $(S)$ - $\alpha$-fluoro aldehydes $\mathbf{8}$, the $R$ enantiomers do not react with erythrulose enolate $\mathbf{1}_{\mathbf{B}}$ at all (Scheme 5). When applied to model aldehyde $(R)-\mathbf{2 3 c}$, our theoretical calculations predict that the Cornforth TS-6A and the FA TS-6B have approximately the same energy content (Figure 9). Indeed, TS6A exhibits a destabilizing syn-pentane interaction that overcomes even the favorable factor of a Cornforth-type conformation $\left(\varphi_{2}=170.2^{\circ}\right)$. As regards TS-6B, it adopts a FA conformation $\left(\varphi_{1}=167.9^{\circ}\right)$ but the structure is destabilized here by a strong $\mathrm{C}=\mathrm{O} / \mathrm{C}-\mathrm{F}$ dipolar repulsion, which causes it to have more or less the same energy content as TS-6A. This alone does not explain the observed absence of reactivity but it is worth noting that, if we compare the absolute energy contents of TS-6A or TS-6B with that of TS-5A (see Supporting Information), we observe that TS-6A and TS-6B are destabilized by approximately $2.8 \mathrm{kcal} \mathrm{mol}^{-1}$ relative to TS-5A. This fact may explain the lack of reactivity of $(R)-\alpha-$ fluoro aldehydes in this reaction because the reactions must traverse high energy barriers in any case. Again, this agrees very well with our qualitative mechanistic proposals (Scheme 5 and 6). It is also worth noting here that the same behavior is observed with Evans chiral enolate $\mathbf{1 8}_{\mathbf{B}}$, which reacts very well with $\alpha$-fluoro aldehydes of one configuration ( $R$ in this case) but not at all with the $S$ antipodes (Scheme 12). 


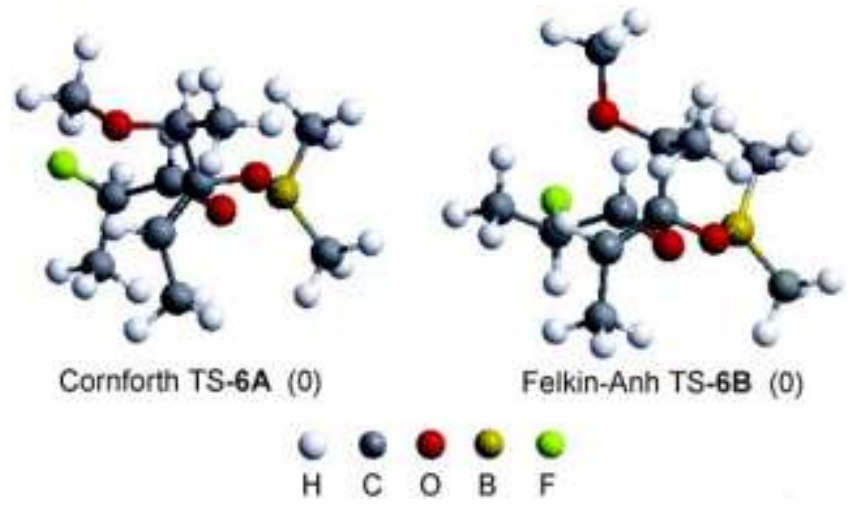

Figure 9. Transition states for the addition of 22 to $(R)-23 \mathrm{c}$ (relative energies in $\mathrm{kcal} \mathrm{mol}^{-1}$ ).

\section{Conclusion}

The doubly diastereoselective aldol reactions of a (Z)-boron enolate of chiral ketone $\mathbf{1}$ with $\alpha$-chiral aldehydes have been investigated from the experimental point of view. As in the recent disclosure on achiral enolates by Evans and co-workers, ${ }^{\text {th }}$ cyclic transition states of the Zimmerman-Traxler type have been assumed with no chelation issues involved. Relying upon the experimental findings with this and other enolizable compounds, and on the theoretical calculations on model reactions, we have summarized the results of the aforementioned reactions within a unified general concept in which several factors must be taken into account. These factors are:

1) Syn-pentane steric repulsions between the OTBS group on the enolate and one aldehyde non-hydrogen $\alpha$-substituent are energetically important interactions that must be avoided through appropriate $\mathrm{C}$-C bond rotation.

2) For aldehydes $\alpha$-substituted with very electronegative heteroatoms (F, O), Cornforth-type dipolar repulsions during the TS are energetically more important than the stereoelectronic advantage associated with the Felkin-Anh conformation. Thus, the shapes of the transition states are likely dictated by groundstate conformational factors of the aldehydes, where such dipolar repulsions are of paramount importance.

3) For aldehydes containing less electronegative a-heteroatoms (N), either Felkin-Anh or Cornforth transition states may dominate according to the particular situation. For those containing only carbon $\alpha$ substituents, the Felkin-Anh $\pi$-facial bias is not very strong, and the stereocontrol is mostly exerted by the chiral enolate. Again, the stereochemical course is dictated here by the need to avoid syn-pentane steric repulsions.

In the cases under study in the present paper with ketone $\mathbf{1}$ as the enol-forming compound, factor 1) can be considered dominant in general terms and determines the reaction course for aldehydes containing nitrogen or only-carbon $\alpha$-substituents, with either $R$ or $S$ configuration. For aldehydes, which contain $\alpha$ fluorine or $\alpha$-oxygen atoms, factors 1) and 2) are comparable in magnitude and one is unable to dominate the other. In the case of the $S$ enantiomers both factors cooperate (matched pairs) and give rise to highly stereoselective reactions. For the $R$ enantiomers, however, both factors counteract each other (mismatched pairs), resulting in slow and unselective reactions.

\section{Experimental Section}

General methods: ${ }^{1} \mathrm{H}$ and ${ }^{13} \mathrm{C}$ NMR spectra were recorded at $500 \mathrm{MHz}$ and $125 \mathrm{MHz}$, respectively, in $\mathrm{CDCl}_{3}$ solution at $258 \mathrm{C}$. ${ }^{19} \mathrm{~F}$ NMR spectra were recorded at $470.25 \mathrm{MHz}$. ${ }^{13} \mathrm{C}$ NMR signal multiplicities were determined with the DEPT pulse sequence. ${ }^{13} \mathrm{C}$ signals are sharp singlets, except where otherwise indicated. The non-quaternary signals were assigned by means of 2D HMQC experiments. Solvent signals taken as reference were ${ }^{1} \mathrm{H}(\delta=7.25)$ and ${ }^{13} \mathrm{C}(\delta=77) .{ }^{19} \mathrm{~F}$ NMR $\delta$ values are referenced to $\mathrm{CFCl}_{3}(\delta$ $=0)$ but the internal standard used was $\mathrm{C}_{6} \mathrm{~F}_{6}(\delta=-162.3 \mathrm{ppm}) .{ }^{30}$ Mass spectra were run in either the electron impact (EIMS, $70 \mathrm{eV}$ ) or the fast atom bombardment mode (FABMS, $m$-nitrobenzyl alcohol matrix). IR data, which were measured as films on $\mathrm{NaCl}$ plates (oils) or as $\mathrm{KBr}$ pellets (solids), are given only when relevant functions $(\mathrm{C}=\mathrm{O}, \mathrm{OH})$ are present. Optical rotations were measured at $25^{\circ} \mathrm{C}$. Reactions 
which required an inert atmosphere were carried out under dry $\mathrm{N}_{2}$ with flame-dried glassware. Commercial reagents were used as received. THF and $\mathrm{Et}_{2} \mathrm{O}$ were freshly distilled from sodiumbenzophenone ketyl. Dichloromethane was freshly distilled from $\mathrm{CaH}_{2}$. Tertiary amines were freshly distilled from $\mathrm{KOH}$. Unless detailed otherwise, "work-up" means pouring the reaction mixture into satd. aqueous $\mathrm{NH}_{4} \mathrm{Cl}$ (basic reaction media) or $\mathrm{NaHCO}_{3}$ (acid reaction media), extraction with the indicated solvent, additional washing with $5 \%$ aq $\mathrm{NaHCO}_{3}$ or $5 \%$ aq $\mathrm{HCl}$, respectively, then again with brine, drying over anhydrous $\mathrm{Na}_{2} \mathrm{SO}_{4}$ or $\mathrm{MgSO}_{4}$ and solvent removal under reduced pressure. This was followed by chromatography of the residue on a silica gel column (60-200 $\mu \mathrm{m})$ with the indicated solvent mixture. Where solutions were filtered through a Celite pad, the pad was additionally rinsed with the same solvent used, and the washing solutions were incorporated into the main organic layer.

General experimental procedure for aldol additions of ketone 1 mediated by dicyclohexyl boron chloride: $\mathrm{Chx}_{2} \mathrm{BCl}$ (neat, $395 \mu \mathrm{L}$, ca. $1.8 \mathrm{mmol}$ ) was added under Ar by syringe to an ice-cooled solution of $\mathrm{Et}_{3} \mathrm{~N}(280 \mu \mathrm{L}, 2 \mathrm{mmol})$ in anhydrous $\mathrm{Et}_{2} \mathrm{O}(5 \mathrm{~mL})$. Erythrulose derivative $\mathbf{1}(1 \mathrm{mmol})$ was dissolved in anhydrous $\mathrm{Et}_{2} \mathrm{O}(5 \mathrm{~mL})$ and added dropwise by syringe to the reagent solution. The reaction mixture was then stirred for $30 \mathrm{~min}$. After dropwise addition of a solution of the appropriate aldehyde (freshly prepared, $4 \mathrm{mmol})$ in anhydrous ether $(6 \mathrm{~mL})$, the reaction mixture was stirred at $0^{\circ} \mathrm{C}$ for $6 \mathrm{~h}$. Then,

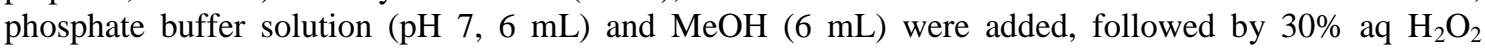
solution $(3 \mathrm{~mL})$. After stirring for $1 \mathrm{~h}$ at room temperature, the mixture was worked up (extraction with $\mathrm{Et}_{2} \mathrm{O}$ ). Solvent removal in vacuo and column chromatography of the residue on silica gel (hexanes/EtOAc mixtures) afforded the aldol addition product. Chemical yields and d.r. values are given in the main text.

$(2 R, 3 R, 4 S)-5-(B e n z y l o x y)-2-(t e r t-b u t y l d i m e t h y l s i l y l o x y)-1-\{(S)-2,2-d i m e t h y l-1,3-d i o x o l a n-4-y l)\}-4-$ fluoro-3-hydroxypentan-1-one (10 a): oil; $[\alpha]_{\mathrm{D}}=-63.3\left(c=0.98\right.$ in $\left.\mathrm{CHCl}_{3}\right)$; $\left.{ }^{1} \mathrm{H} \mathrm{NMR} \mathrm{(500} \mathrm{MHz}, \mathrm{CDCl}_{3}\right)$ : $\delta=7.35-7.25$ (br m, 5H; aromatic), 5.09 (br s, 1H; H-2), 4.65 (br s, 2H;OCH${ }_{2} \mathrm{Ph}$ ), 4.60-4.50 (partly overlapped m, 1H; H-4), 4.60 (dd, J=7,5 Hz, 1H; H-4'), 4.36 (br t, J $\approx 10 \mathrm{~Hz}, 1 \mathrm{H} ; \mathrm{H}-3$ ), 4.22 (dd, $J=8.5,7$ $\mathrm{Hz}, 1 \mathrm{H} ; \mathrm{H}-5$ 'a), 4.11 (dd, $J=8.5,5 \mathrm{~Hz}, 1 \mathrm{H} ; \mathrm{H}-5$ 'b), 3.91 (ddd, $\left.{ }^{3} J_{\mathrm{H}, \mathrm{F}}=27.5 \mathrm{~Hz}, J=12,2 \mathrm{~Hz}, 1 \mathrm{H} ; \mathrm{H}-5 \mathrm{a}\right), 3.81$ $\left(\mathrm{ddd},{ }^{3} J_{\mathrm{H}, \mathrm{F}}=29 \mathrm{~Hz}, J=12,5 \mathrm{~Hz}, 1 \mathrm{H} ; \mathrm{H}-5 \mathrm{~b}\right), 2.40(\mathrm{~d}, J=10 \mathrm{~Hz}, 1 \mathrm{H} ; \mathrm{OH}), 1.47$ (s, 3H; acetonide $\left.M e\right), 1.39$ (s, 3H; acetonide $\mathrm{Me}$ ), 0.95 (s, 9H; $\left.\mathrm{Me}_{3} \mathrm{CSi}\right), 0.12$ (s, 3H; MeSi), $0.05 \mathrm{ppm}(\mathrm{s}, 3 \mathrm{H} ; \mathrm{MeSi}) ;{ }^{13} \mathrm{C}$ NMR (125 $\mathrm{MHz}_{\mathrm{CDCl}}$ ): $\delta=208.0(\mathrm{C}-1), 137.9$ (aromatic $\mathrm{C}_{\mathrm{q}}$ ), 128.4 (x 2), 127.7, 127.6 (x 2) (aromatic CH), 111.2 (acetonide $\mathrm{C}_{\mathrm{q}}$ ), 91.5/90.1 (d, $\left.{ }^{1} J_{\mathrm{C}, \mathrm{F}} \approx 179 \mathrm{~Hz}, \mathrm{C}-4\right), 78.6\left(\mathrm{C}-4\right.$ '), 74.7 (br s, C-2), $73.6\left(\mathrm{OCH}_{2} \mathrm{Ph}\right), 69.5$ (d, $\left.{ }^{2} J_{\mathrm{C}, \mathrm{F}} \approx 19.2 \mathrm{~Hz}, \mathrm{C}-5\right), 68.7\left(\mathrm{~d},{ }^{2} J_{\mathrm{C}, \mathrm{F}} \approx 26.6 \mathrm{~Hz}, \mathrm{C}-3\right), 66.7$ (C-5'), 26.0 (acetonide $\mathrm{Me}$ ), 25.7 (x 3, Me ${ }_{3} \mathrm{CSi}$ ), 24.9 (acetonide $\mathrm{Me}), 18.4\left(\mathrm{C}_{\mathrm{q}}-\mathrm{Si}\right),-4.7(\mathrm{MeSi}),-5.6 \mathrm{ppm}(\mathrm{MeSi}) ;{ }^{19} \mathrm{~F} \mathrm{NMR}\left(470 \mathrm{MHz}, \mathrm{CDCl}_{3}\right): \delta=$ $-192.8 \mathrm{ppm}(\mathrm{dt}, J \approx 49,27.5 \mathrm{~Hz})$; IR: $\tilde{v}=3460(\mathrm{br}, \mathrm{OH}), 1735(\mathrm{C}=\mathrm{O}) \mathrm{cm}^{-1}$; HRMS (EI): $\mathrm{m} / z$ : calcd for $\mathrm{C}_{23} \mathrm{H}_{37} \mathrm{FO}_{6} \mathrm{Si}$ _Me: 441.2108; found: 441.2098 ([M+Me], 2), 399 (1), 341 (7), 159 (15), 101 (22), 91 (100); elemental analysis calcd (\%) for $\mathrm{C}_{23} \mathrm{H}_{37} \mathrm{FO}_{6} \mathrm{Si}$ : C 60.50, H 8.17; found: C 60.68, H 8.31.

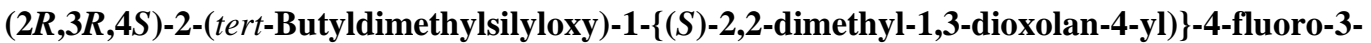
hydroxy-5-phenylpentan-1-one (10 b): oil; $[\alpha]_{\mathrm{D}}=-75.3\left(c=0.95\right.$ in $\left.\mathrm{CHCl}_{3}\right) ;{ }^{1} \mathrm{H} \mathrm{NMR}\left(500 \mathrm{MHz}, \mathrm{CDCl}_{3}\right)$ : $\delta=7.35-7.25$ (brm, 5H; aromatic), 5.09 (br s, $1 \mathrm{H} ; \mathrm{H}-2), 4.60$ (dtd, $\left.{ }^{2} J_{\mathrm{H}, \mathrm{F}}=48 \mathrm{~Hz}, J=8.3,2.6 \mathrm{~Hz}, 1 \mathrm{H} ; \mathrm{H}-4\right)$, 4.59 (dd, $J=7.6,5.2 \mathrm{~Hz}, 1 \mathrm{H} ; \mathrm{H}-4$ '), 4.21 (dd, J=9,7.6 Hz, 1H; H-5'a), 4.12 (overlapped m, 1H; H-3), 4.11 (dd, $J=9,5.2 \mathrm{~Hz}, 1 \mathrm{H} ; \mathrm{H}-5$ 'b), 3.30 (ddd, $\left.{ }^{2} J_{\mathrm{H}, \mathrm{F}}=35 \mathrm{~Hz}, J=15,2.6 \mathrm{~Hz}, 1 \mathrm{H} ; \mathrm{H}-5 \mathrm{a}\right), 3.00$ (ddd, ${ }^{2} J_{\mathrm{H}, \mathrm{F}}=24.6 \mathrm{~Hz}$, $J=15,8.3 \mathrm{~Hz}, 1 \mathrm{H} ; \mathrm{H}-5 \mathrm{~b}), 2.50(\mathrm{~d}, J=11 \mathrm{~Hz}, 1 \mathrm{H} ; \mathrm{OH}), 1.43(\mathrm{~s}, 3 \mathrm{H}$; acetonide $M e), 1.37$ (s, 3H; acetonide $\mathrm{Me}$ ), 0.94 (s, 9H; $\left.\mathrm{Me}_{3} \mathrm{CSi}\right), 0.11$ (s, 3H; MeSi), $0.03 \mathrm{ppm}(\mathrm{s}, 3 \mathrm{H} ; \mathrm{MeSi}) ;{ }^{13} \mathrm{C} \mathrm{NMR}\left(125 \mathrm{MHz}, \mathrm{CDCl}_{3}\right): \delta$ =208.1 (C-1), $137.1\left(\operatorname{aromatic} \mathrm{C}_{\mathrm{q}}\right), 129.5(\mathrm{x} 2), 128.4(\mathrm{x} 2), 126.6(\operatorname{aromatic} \mathrm{CH}), 111.2\left(\right.$ acetonide $\left.\mathrm{C}_{\mathrm{q}}\right)$, 92.6/91.2 (d, $\left.{ }^{1} J_{\mathrm{C}, \mathrm{F}} \approx 178 \mathrm{~Hz}, \mathrm{C}-4\right), 78.7$ (C-4'), 74.7 (d, $\left.{ }^{3} J_{\mathrm{C}, \mathrm{F}} \approx 2.2 \mathrm{~Hz}, \mathrm{C}-2\right), 71.3$ (d, $\left.{ }^{2} J_{\mathrm{C}, \mathrm{F}} \approx 26.5 \mathrm{~Hz}, \mathrm{C}-3\right)$, 66.8 (C-5'), 38.0 (d, ${ }^{2} J_{\mathrm{C}, \mathrm{F}} \approx 19.7 \mathrm{~Hz}, \mathrm{C}-5$ ), 25.9 (acetonide $\mathrm{Me}$ ), 25.7 (x 3, Me ${ }_{3} \mathrm{CSi}$ ), 24.9 (acetonide $M e$ ), $18.4\left(\mathrm{C}_{\mathrm{q}}-\mathrm{Si}\right),-4.7(\mathrm{MeSi}),-5.6 \mathrm{ppm}(\mathrm{MeSi}) ;{ }^{19} \mathrm{~F} \mathrm{NMR}\left(470 \mathrm{MHz}, \mathrm{CDCl}_{3}\right): \delta=-188.2 \mathrm{ppm}(\mathrm{ddd}, J \approx 48, \approx 35$, $\approx 24.5 \mathrm{~Hz}) ;: \mathrm{v}^{\sim}=3550(\mathrm{br}, \mathrm{OH}), 1735(\mathrm{C}=\mathrm{O}) \mathrm{cm}^{-1}$; HRMS(EI): $m / z$ : calcd for $\mathrm{C}_{22} \mathrm{H}_{35} \mathrm{FO}_{5} \mathrm{Si}-\mathrm{Me}: 411.2003$

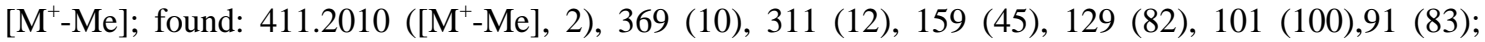
elemental analysis calcd (\%) for $\mathrm{C}_{22} \mathrm{H}_{35} \mathrm{FO}_{5} \mathrm{Si}$ : C 61.94, H 8.27; found: C 61.77, H 8.49.

$(2 R, 3 S, 4 S)-2-(t e r t-B u t y l d i m e t h y l s i l y l o x y)-4-(d i b e n z y l a m i n o)-1-\{(S)-2,2-d i m e t h y l-1,3-d i o x o l a n-4-y l)\}-$ 3-hydroxypentan-1-one (11 a): oil; $[\alpha]_{D}=-47.6$ (c=1.88 in $\mathrm{CHCl}_{3}$ ); ${ }^{1} \mathrm{H} \mathrm{NMR}\left(500 \mathrm{MHz}, \mathrm{CDCl}_{3}\right)$ : $\delta=7.45-7.20$ (m, 10H, aromatic), 4.95 (br s, $1 \mathrm{H} ; \mathrm{H}-2), 4.60$ (br t, $J \approx 6.5 \mathrm{~Hz}, 1 \mathrm{H} ; \mathrm{H}-4$ '), 4.22 (m, 1H; H-3), 4.20 (m, 2H; H-5a/5b), 3.80 (br d, J=14 Hz, 2H; $\mathrm{NCH}_{2} \mathrm{Ph}$ ), 3.63 (br d, J=14 Hz, 2H; $\mathrm{NCH}_{2} \mathrm{Ph}$ ), 3.07 (quint, $J \approx 6.5 \mathrm{~Hz}, 1 \mathrm{H} ; \mathrm{H}-4), 2.40$ (br s, $1 \mathrm{H} ; \mathrm{OH}), 1.49$ (s, 3H; acetonide $M e$ ), 1.46 (s, 3H; acetonide $M e$ ), 1.16 (d, J=6.5 Hz, 3H; H-5), 0.86 (s, 9H; Me3CSi), 0.03 (s, 3H; MeSi), -0.20 ppm (s, 3H; MeSi); ${ }^{13} \mathrm{C}$ NMR (125 MHz, $\mathrm{CDCl}_{3}$ ): $\delta=207.7(\mathrm{C}-1), 140.2$ (x 2, aromatic $\mathrm{C}_{\mathrm{q}}$ ), 128.7 (x4), $128.2(\mathrm{x} 4), 126.9$ (x 2) 
(aromatic $\mathrm{CH}$ ), 110.7 (acetonide $\mathrm{C}_{\mathrm{q}}$ ), 78.3 (C-2 or C-4'), 78.0 (C-4' or C-2), 72.7 (C-3), 66.3 (C-5'), 56.5 (C-4), 54.0 (x 2, $\mathrm{NCH}_{2} \mathrm{Ph}$ ), 26.0 (acetonide $\mathrm{Me}$ ), 25.8 (x 3, $\mathrm{Me}_{3} \mathrm{CSi}$ ), 25.0 (acetonide $\mathrm{Me}$ ), $18.3\left(\mathrm{C}_{\mathrm{q}}-\mathrm{Si}\right.$ ), 9.7 (C-5), -4.6 (MeSi), -5.4 ppm (MeSi); IR: $\tilde{v}=3550$ (br, OH), $1733(\mathrm{C}=\mathrm{O}) \mathrm{cm}^{-1}$; HRMS (FAB): $m / z$ : calcd for $\mathrm{C}_{30} \mathrm{H}_{46} \mathrm{NO}_{5} \mathrm{Si}$ : 528.3145, $\left[\mathrm{M}+\mathrm{H}^{+}\right]$; found: 528.3147; elemental analysis calcd $(\%)$ for $\mathrm{C}_{30} \mathrm{H}_{45} \mathrm{NO}_{5} \mathrm{Si}$ : C 68.27, $\mathrm{H} 8.59$; found: C 68.47, $\mathrm{H} 8.49$.

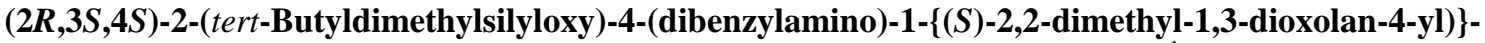
3-hydroxy-5-phenylpentan-1-one (11 b): oil; $[\alpha]_{\mathrm{D}}=-52.3\left(c=1.04\right.$ in $\left.\mathrm{CHCl}_{3}\right)$; ${ }^{1} \mathrm{H}$ NMR $(500 \mathrm{MHz}$, $\mathrm{CDCl}_{3}$ ): $\delta=7.35-7.20$ (br m, 15H; aromatic), 4.88 (d, J=3 Hz, 1H; H-2), 4.35-4.30 (m, 2H; H-3/H-4'), 4.15 (d, J=6.6 Hz, 2H; H-5'a/5'b), 3.82 (d, J=14.3 Hz, 2H; $\mathrm{NCH}_{2} \mathrm{Ph}$ ), 3.68 (d, J=14.3 Hz, 2H; $\mathrm{NCH}_{2} \mathrm{Ph}$ ), 3.22 (m, 1H; H-4), 3.12 (dd, $J=14,8.4 \mathrm{~Hz}, 1 \mathrm{H} ; \mathrm{H}-5 \mathrm{a}), 2.96$ (dd, $J=14,5.7 \mathrm{~Hz}, 1 \mathrm{H} ; \mathrm{H}-5 \mathrm{~b}), 2.40$ (d, $J=9 \mathrm{~Hz}$, $1 \mathrm{H} ; \mathrm{OH}), 1.55$ (s, 3H; acetonide $M e), 1.46(\mathrm{~s}, 3 \mathrm{H}$; acetonide $M e), 0.82\left(\mathrm{~s}, 9 \mathrm{H} ; \mathrm{Me}_{3} \mathrm{CSi}\right),-0.02(\mathrm{~s}, 3 \mathrm{H}$; $\mathrm{MeSi}$ ), $-0.23 \mathrm{ppm}(\mathrm{s}, 3 \mathrm{H} ; \mathrm{MeSi}) ;{ }^{13} \mathrm{C} \mathrm{NMR}\left(125 \mathrm{MHz}, \mathrm{CDCl}_{3}\right): \delta=207.9$ (C-1), 140.6, 139.8 (x 2) (aromatic $\mathrm{C}_{\mathrm{q}}$ ), 129.8 (x 2), 128.8 (x 4), 128.2 (x 4), 128.1 (x 2), 126.8 (x 2), 125.8 (aromatic CH), 110.9 (acetonide $\mathrm{C}_{\mathrm{q}}$ ), 78.5 (C-2 or C-4'), 76.8 (C-4' or C-2), 70.9 (C-3), 66.5 (C-5'), 61.5 (C-4), 54.1 (x 2, $\mathrm{NCH}_{2} \mathrm{Ph}$ ), 32.4 (C-5), 26.2 (acetonide $\mathrm{Me}$ ), 25.8 (x 3, Me ${ }_{3} \mathrm{CSi}$ ), 24.9 (acetonide $\mathrm{Me}$ ), $18.2\left(\mathrm{C}_{\mathrm{q}}-\mathrm{Si}\right),-4.8$ (MeSi), -5.2 ppm (MeSi); IR: $\tilde{v}=3540(\mathrm{br}, \mathrm{OH}), 1733(\mathrm{C}=\mathrm{O}) \mathrm{cm}^{-1}$; HRMS (EI): $\mathrm{m} / z$ : calcd for

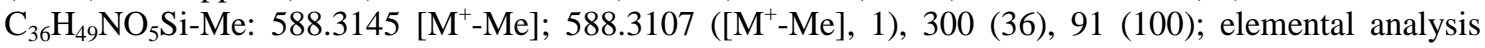
calcd (\%) for $\mathrm{C}_{36} \mathrm{H}_{49} \mathrm{NO}_{5} \mathrm{Si}$ : C 71.60, $\mathrm{H}$ 8.18; found: C 71.45, H 8.35.

$(2 R, 3 S, 4 S)-2-($ tert-Butyldimethylsilyloxy)-5-(tert-butyldiphenylsilyloxy)-4-(dibenzylamino)-1- $\{(S)$ 2,2-dimethyl-1,3-dioxolan-4-yl)\}-3-hydroxypentan-1-one (11 c): oil; $[\alpha]_{\mathrm{D}}=$ _22.4 $\left(c=1.34\right.$ in $\left.\mathrm{CHCl}_{3}\right) ;{ }^{1} \mathrm{H}$ NMR (500 MHz, $\mathrm{CHCl}_{3}$ ): $\delta=7.80-7.75$ (m, 4H; aromatic), 7.50-7.35 (br m, 10H; aromatic), 7.30-7.20

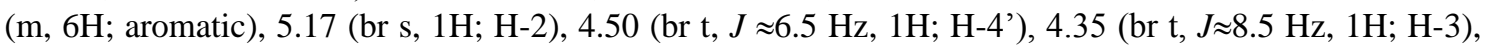
4.20-4.05 (br m, 3H; H-5a/H-5'a/H-5'b), 4.00 (br d, J=14 Hz, 2H; NCH $2 \mathrm{Ph}$ ), 3.98 (overlapped m, 1H; H$5 b$ ), 3.85 (br d, $J=14 \mathrm{~Hz}, 2 \mathrm{H} ; \mathrm{NCH}_{2} \mathrm{Ph}$ ), 3.23 (br td; J $\left.\approx 6.5,5 \mathrm{~Hz}, 1 \mathrm{H} ; \mathrm{H}-4\right), 2.60$ (d, J=10 Hz, 1H; OH), 1.43 (s, 3H; acetonide $M e$ ), 1.42 (s, 3H; acetonide $M e$ ), 1.14 (s, 9H; $\mathrm{Me}_{3} \mathrm{CSi}$ ), 0.85 (s, 9H; $\mathrm{Me}_{3} \mathrm{CSi}$ ), 0.04 (s, 3H; MeSi), - $0.18 \mathrm{ppm}(\mathrm{s}, 3 \mathrm{H} ; \mathrm{MeSi}) ;{ }^{13} \mathrm{C} \mathrm{NMR}\left(125 \mathrm{MHz}, \mathrm{CDCl}_{3}\right): \delta=207.6(\mathrm{C}-1), 140.1$ (x 2$), 135.8$ (x 2), 135.7 (x 2), 133.3, 133.1 (aromatic $\mathrm{C}_{\mathrm{q}}$ ), 129.8, 129.7, 128.8 (x 4), 128.2 (x 4), 127.8 (x 2), 127.7 (x 2), 127.0 (x 2) (aromatic CH), 110.8 (acetonide $\mathrm{C}_{\mathrm{q}}$ ), 78.1 (C-2 or C-4'), 77.0 (C-4' or C-2), 71.7 (C-3), 66.1 (C-5'), 62.4 (C-5), 62.1 (C-4), 55.1 (x 2, $\mathrm{NCH}_{2} \mathrm{Ph}$ ), 27.0 (x 3, Me $3 \mathrm{Si}$ ), 26.0 (x 3, Me $\mathrm{CSSi}_{3}, 25.9$ (acetonide $\mathrm{Me}$ ), 25.1 (acetonide $\mathrm{Me}), 19.2,18.4\left(\mathrm{C}_{\mathrm{q}}-\mathrm{Si}\right),-4.3(\mathrm{MeSi}),-5.0 \mathrm{ppm}(\mathrm{MeSi})$; IR: $\tilde{v}=3550(\mathrm{br}$, $\mathrm{OH}), 1733(\mathrm{C}=\mathrm{O}) \mathrm{cm}^{-1}$; HRMS (FAB): $\mathrm{m} / z$ : calcd for $\mathrm{C}_{46} \mathrm{H}_{64} \mathrm{NO}_{6} \mathrm{Si}_{2}:$ 782.4272, [M+H $\mathrm{H}^{+}$; found: 782.4310; elemental analysis calcd (\%) for $\mathrm{C}_{46} \mathrm{H}_{63} \mathrm{NO}_{6} \mathrm{Si}_{2}$ : C 70.64, H 8.12; found: C 70.78, H 8.01.

(2R,3S,4R)-2-(tert-Butyldimethylsilyloxy)-4-(dibenzylamino)-1-\{(S)-2,2-dimethyl-1,3-dioxolan-4yl)\}-3-hydroxypentan-1-one (12 a): oil; $[\alpha]_{\mathrm{D}}=-52.7$ (c=1.56 in $\left.\mathrm{CHCl}_{3}\right) ;{ }^{1} \mathrm{H} \mathrm{NMR}\left(500 \mathrm{MHz}, \mathrm{CDCl}_{3}\right)$ : $\delta=7.35-7.20$ (br m, 10H; aromatic), 4.78 (br s, 1H; H-2), 4.60 (dd, J=7.5, $5 \mathrm{~Hz}, 1 \mathrm{H} ; \mathrm{H}-4$ '), 4.20 (dd, $J=8.5,5 \mathrm{~Hz}, 2 \mathrm{H} ; \mathrm{H}-5$ 'a/OH), 4.08 (m, 2H; H-3/H-5'b), 3.87 (br d, J=13.2 Hz, 2H; $\mathrm{NCH}_{2} \mathrm{Ph}$ ), 3.40 (br d, $J=13.2 \mathrm{~Hz}, 2 \mathrm{H} ; \mathrm{NCH}_{2} \mathrm{Ph}$ ), 3.05 (dq, J=9.5, $\left.6.6 \mathrm{~Hz}, 1 \mathrm{H} ; \mathrm{H}-4\right), 1.43$ (s, 3H; acetonide $\mathrm{Me}$ ), 1.40 (s, 3H; acetonide $M e), 1.12$ (d, J=6.6 Hz, 3H; H-5), 0.74 (s, 9H; $\left.M e_{3} \mathrm{CSi}\right), 0.03$ (s, 3H; MeSi), - $0.11 \mathrm{ppm}(\mathrm{s}, 3 \mathrm{H}$; $\mathrm{MeSi}$ ); ${ }^{13} \mathrm{C}$ NMR $\left(125 \mathrm{MHz}, \mathrm{CDCl}_{3}\right.$ ): $\delta=207.7$ (C-1), 138.7 (x 2) (aromatic $\mathrm{C}_{\mathrm{q}}$ ), 128.9 (x 4), 128.5 (x 4), 127.3 (x 2) (aromatic CH), 110.5 (acetonide Cq), 78.6 (C-2 or C-4'), 76.1 (C-4' or C-2), 71.6 (C-3), 66.2 (C-5'), 54.0 (C-4), 53.5 (x 2, $\mathrm{NCH}_{2} \mathrm{Ph}$ ), 26.1 (acetonide $\mathrm{Me}$ ), 25.8 (x 3, Me ${ }_{3} \mathrm{CSi}$ ), 25.1 (acetonide $\mathrm{Me}$ ), $18.3\left(\mathrm{C}_{\mathrm{q}}-\mathrm{Si}\right), 8.0(\mathrm{C}-5),-4.3(\mathrm{MeSi}),-5.4 \mathrm{ppm}(\mathrm{MeSi})$; IR: $\tilde{v}=3400(\mathrm{br}, \mathrm{OH}), 1738(\mathrm{C}=\mathrm{O}) \mathrm{cm}^{-1}$; HRMS (FAB): $m / z: 528.3142\left[\mathrm{M}+\mathrm{H}^{+}\right]$; calcd for $\mathrm{C}_{30} \mathrm{H}_{46} \mathrm{NO}$ :Si, 528.3145; elemental analysis calcd $(\%)$ for $\mathrm{C}_{30} \mathrm{H}_{45} \mathrm{NO}_{5} \mathrm{Si}$ : C 68.27, $\mathrm{H}$ 8.59; found: C 68.41, H 8.66.

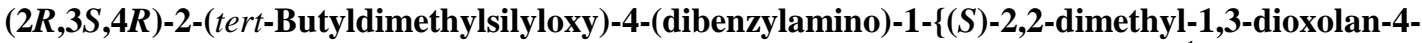
yl)\}-3-hydroxy-5-phenylpentan-1-one (12 b): oil; $[\alpha]_{\mathrm{D}}=-50.2\left(c=1.5\right.$ in $\left.\mathrm{CHCl}_{3}\right) ;{ }^{1} \mathrm{H} \mathrm{NMR}(500 \mathrm{MHz}$, $\mathrm{CDCl}_{3}$ ): $\delta=7.45-7.20$ (br m, 15H; aromatic), 5.10 (d, J=2.5 Hz, 1H; H-2), 4.50 (br s, $\left.1 \mathrm{H} ; \mathrm{OH}\right), 4.44$ (dd, $\left.J=7.5,5 \mathrm{~Hz}, 1 \mathrm{H} ; \mathrm{H}^{\prime} 4^{\prime}\right), 4.25$ (dd, $J=8.6,5 \mathrm{~Hz}, 1 \mathrm{H} ; \mathrm{H}-5$ 'a), 4.17 (dd, J=9.5, $2.5 \mathrm{~Hz}, 1 \mathrm{H} ; \mathrm{H}-3$ ), 4.10 (dd, $J=8.6,7.5 \mathrm{~Hz}, 1 \mathrm{H}$; H- 5'b), 4.00-3.90 (br m, 2H; $\mathrm{NCH}_{2} \mathrm{Ph}$ ), 3.60-3.50 (br m, 2H; NCH $2 \mathrm{Ph}$ ), 3.35 (td, $J=9.5,3.6 \mathrm{~Hz}, 1 \mathrm{H} ; \mathrm{H}-4), 3.22$ (dd, $J=14.3,3.6 \mathrm{~Hz}, 1 \mathrm{H} ; \mathrm{H}-5 \mathrm{a}), 3.06$ (dd, $J=14.3,9.5 \mathrm{~Hz}, 1 \mathrm{H} ; \mathrm{H}-5 \mathrm{~b}$ ), 1.52 (s, 3H; acetonide $\mathrm{Me}$ ), 1.50 (s, 3H; acetonide $\mathrm{Me}$ ), 0.91 (s, 9H; $\mathrm{Me}_{3} \mathrm{CSi}$ ), 0.10 (s, 3H; $\left.\mathrm{MeSi}\right), 0.00 \mathrm{ppm}(\mathrm{s}$, $3 \mathrm{H} ; \mathrm{MeSi}$ ); ${ }^{13} \mathrm{C}$ NMR (125 MHz, $\mathrm{CDCl}_{3}$ ): $\delta=207.7$ (C-1), 139.9, 138.8 (br,x2) (aromatic $\mathrm{C}_{\mathrm{q}}$ ), 129.8 (x 2), 129.2 (x 4), 128.5 (x 2), 128.3 (x 4), 127.2 (x 2), 126.4 (aromatic $\mathrm{CH}$ ), 110.5 (acetonide $\mathrm{C}_{\mathrm{q}}$ ), 78.9 (C-2 or C- 4'), 76.0 (C-4' or C-2), 71.5 (C-3), 65.8 (C-5'), 59.8 (C-4), 53.8 (br,x2, $\left.\mathrm{NCH}_{2} \mathrm{Ph}\right), 34.2$ (C-5), 26.2 (acetonide $\mathrm{Me}$ ), 25.9 (x 3, Me $3 \mathrm{CSi}$ ), 25.0 (acetonide $\mathrm{Me}), 18.3\left(\mathrm{C}_{\mathrm{q}}-\mathrm{Si}\right),-4.4(\mathrm{MeSi}),-5.0 \mathrm{ppm}(\mathrm{MeSi})$; IR: 
$\tilde{v}=3340(\mathrm{br}, \mathrm{OH}), 1736(\mathrm{C}=\mathrm{O}) \mathrm{cm}^{-1}$; HRMS (EI): $\mathrm{m} / z$ : calcd for $\mathrm{C}_{36} \mathrm{H}_{49} \mathrm{NO}_{5} \mathrm{Si}-t \mathrm{Bu}$ : 546.2675 ; found: $546.2628\left(\left[\mathrm{M}^{+}-\mathrm{tBu}\right], 1\right), 300$ (71), 91 (100); elemental analysis calcd (\%) for $\mathrm{C}_{36} \mathrm{H}_{49} \mathrm{NO}_{5} \mathrm{Si}: \mathrm{C} 71.60, \mathrm{H}$ 8.18, found: C 71.70, H 8.32.

$(2 R, 3 S, 4 R)-2-($ tert-Butyldimethylsilyloxy)-5-(tert-butyldiphenylsilyloxy)-4-(dibenzylamino)-1- $\{(S)$ 2,2-dimethyl-1,3-dioxolan-4-yl)\}-3-hydroxypentan-1-one (12 c): oil; $[\alpha]_{\mathrm{D}}=-40.2\left(\mathrm{c}=1.28\right.$ in $\left.\mathrm{CHCl}_{3}\right)$; ${ }^{1} \mathrm{H}$ NMR(500 MHz, CDCl3): $\delta=7.80-7.75$ (m, 4H; aromatic), 7.55-7.40 (m, 6H; aromatic), 7.30-7.20 (br

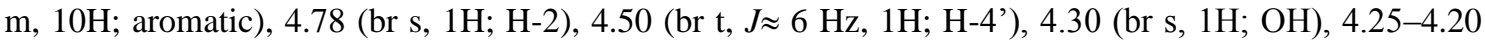
(m, 2H; H-3/H- 5'a), 4.14 (br d, J=11.6 Hz, 1H; H-5a), 4.10-4.00 (m, 3H; H-5'b/ NCH $\mathrm{H}_{2} \mathrm{Ph}$ ), 3.84 (dd, $J=11.6,6.8 \mathrm{~Hz}, 1 \mathrm{H} ; \mathrm{H}-5 \mathrm{~b}$ ), 3.77 (br d, J=13.3 Hz, 2H; NCH $\mathrm{Ph}$ ), 3.15 (m, 1H; H-4), 1.33 (s, 6H; $2 \mathrm{x}$ acetonide $\mathrm{Me}$ ), $1.22\left(\mathrm{~s}, 9 \mathrm{H} ; \mathrm{Me}_{3} \mathrm{CSi}\right), 0.62\left(\mathrm{~s}, 9 \mathrm{H} ; \mathrm{Me}_{3} \mathrm{CSi}\right),-0.06(\mathrm{~s}, 3 \mathrm{H} ; \mathrm{MeSi}),-0.26 \mathrm{ppm}(\mathrm{s}, 3 \mathrm{H}$; $\mathrm{MeSi}$ ); ${ }^{13} \mathrm{C}$ NMR $\left(125 \mathrm{MHz}, \mathrm{CDCl}_{3}\right.$ ): $\delta=206.6$ (C-1), 139.0 (x 2), 135.9 (x 4), 133.0, 132.8 (aromatic $\mathrm{C}_{\mathrm{q}}$ ), 130.0, 129.9, 129.1 (x 4), 128.6 (x 4), 127.9 (x 2), 127.8 (x 2), 127.2 (x 2) (aromatic CH), 110.4 (acetonide $\mathrm{C}_{\mathrm{q}}$ ), 78.4 (C-4'), 76.0 (C-2), 67.4 (C-3), 65.5 (C-5'), 60.5 (C-5), 59.1 (C-4), 54.7 (x 2, $\mathrm{NCH}_{2} \mathrm{Ph}$ ), 27.2 (x 3, $\mathrm{Me}_{3} \mathrm{Si}$ ), 26.0 (acetonide $\mathrm{Me}$ ), 25.8 (x 3, Me 3 Si), 24.9 (acetonide $\mathrm{Me}$ ), 19.2, $18.2\left(\mathrm{C}_{\mathrm{q}^{-}}\right.$ $\mathrm{Si})$, -4.5 (MeSi), -5.4 ppm (MeSi); IR: $\tilde{v}=3365(\mathrm{br}, \mathrm{OH}), 1737(\mathrm{C}=\mathrm{O}) \mathrm{cm}^{-1}$; HRMS (FAB): $m / z$ : calcd for $\mathrm{C}_{46} \mathrm{H}_{64} \mathrm{NO}_{6} \mathrm{Si} 2$ : $782.4272[\mathrm{M}+\mathrm{H}+]$; found: 782.4275; elemental analysis calcd (\%) for $\mathrm{C}_{46} \mathrm{H}_{63} \mathrm{NO}_{6} \mathrm{Si} 2: \mathrm{C}$ 70.64, H 8.12; found: C 70.51, H 8.22.

(3S,4S,5R)-1,3-Bis(tert-butyldimethylsilyloxy)-6-benzyloxy-5-fluoro-4-hydroxyhexan-2-one

(17): oil; $[\alpha]_{\mathrm{D}}=+7.8\left(c=1.6\right.$ in $\left.\mathrm{CHCl}_{3}\right) ; 1 \mathrm{H} \mathrm{NMR}\left(500 \mathrm{MHz}, \mathrm{CDCl}_{3}\right): \delta=7.35-7.25$ (br m, 5H; aromatic), 4.88 (br s, 1H; H-3), 4.62 (s, 2H; H-1a/H-1b), 4.60-4.45 (br m, 1H; H-5), 4.43 (AB system, J=18 Hz, 2H; $\mathrm{OCH}_{2} \mathrm{Ph}$ ), 4.20 (br t, $\left.J \approx 10 \mathrm{~Hz}, 1 \mathrm{H} ; \mathrm{H}-4\right), 3.88$ (ddd, $\left.{ }^{3} J_{\mathrm{H}, \mathrm{F}}=26 \mathrm{~Hz}, J=11.7,2 \mathrm{~Hz}, 1 \mathrm{H} ; \mathrm{H}-6 \mathrm{a}\right), 3.78$ (ddd, $\left.{ }^{3} J_{\mathrm{H}, \mathrm{F}}=29.5 \mathrm{~Hz}, J=11.7,5 \mathrm{~Hz}, 1 \mathrm{H} ; \mathrm{H}-6 \mathrm{~b}\right), 2.50$ (d, $\left.J=10 \mathrm{~Hz}, 1 \mathrm{H} ; \mathrm{OH}\right), 0.97$ (s, 9H; Me $\left.3 \mathrm{CSi}\right), 0.94$ (s, 9H; $\mathrm{Me}_{3} \mathrm{CSi}$ ), 0.12 (s, 3H; MeSi), 0.10 (s, 6H; MeSi), $0.09 \mathrm{ppm}$ (s, 3H; MeSi); $\left.{ }^{13} \mathrm{C} \mathrm{NMR} \mathrm{(125} \mathrm{MHz,} \mathrm{CDCl}_{3}\right): \delta$ $=208.7(\mathrm{C}-2), 137.8\left(\operatorname{aromatic} \mathrm{C}_{\mathrm{q}}\right), 128.3$ (x 2), 127.6 (x 2), 127.5 (aromatic CH), 91.0/89.6 (d, ${ }^{1} J_{\mathrm{C}, \mathrm{F}} \approx$ $178 \mathrm{~Hz}, \mathrm{C}-5), 74.8(\mathrm{C}-3), 73.5\left(\mathrm{OCH} \mathrm{H}_{2} \mathrm{Ph}\right), 69.7 / 69.5\left(\mathrm{~d},{ }^{2} J_{\mathrm{C}, \mathrm{F}} \approx 26 \mathrm{~Hz}, \mathrm{C}-4\right), 69.4 / 69.2\left(\mathrm{C}-6, \mathrm{~d},{ }^{2} J_{\mathrm{C}, \mathrm{F}} \approx 19.5\right.$ $\mathrm{Hz}), 68.3$ (C-1), 25.7 (x 6, Me $3 \mathrm{CSi}), 18.2,18.1\left(\mathrm{C}_{\mathrm{q}}-\mathrm{Si}\right),-4.9(\mathrm{MeSi}),-5.6(\mathrm{MeSi}),-5.7(\mathrm{MeSi}),-5.8 \mathrm{ppm}$ $(\mathrm{MeSi}) ;{ }^{19} \mathrm{~F} \mathrm{NMR} \delta=-192.4 \mathrm{ppm}(\mathrm{dt}, J \approx 47, \approx 28 \mathrm{~Hz}) ; \mathrm{IR}: \tilde{v}=3460(\mathrm{br}, \mathrm{OH}), 1735(\mathrm{C}=\mathrm{O}) \mathrm{cm}^{-1}$; HRMS (EI): $m / z$ : calcd for $\mathrm{C}_{25} \mathrm{H}_{45} \mathrm{FO}_{5} \mathrm{Si}_{2}-\mathrm{HF}: 480.2727 ; 480.2769$ ([M $\left.\left.{ }^{+}-\mathrm{HF}\right], 1\right), 311$ (30), 129 (30), 91 (100); elemental analysis calcd (\%) for $\mathrm{C}_{25} \mathrm{H}_{45} \mathrm{FO}_{5} \mathrm{Si}_{2}$ : C 59.96, $\mathrm{H} 9.06$; found: $\mathrm{C} 60.10, \mathrm{H} 9.22$

(S)-4-Benzyl-3-\{(2S,3S,4R)-4-(tert-butyldiphenylsilyloxy)-3-hydroxy-2-methylpentanoyl $\}$ oxazolidin2-one (19): oil; $[\alpha]_{\mathrm{D}}=+36.7\left(c=2.64\right.$ in $\left.\mathrm{CHCl}_{3}\right) ;{ }^{1} \mathrm{H}$ NMR $\left(500 \mathrm{MHz}, \mathrm{CDCl}_{3}\right): \delta=7.80-7.75(\mathrm{~m}, 4 \mathrm{H}$; aromatic), 7.50-7.25 (br m, 11H; aromatic), 4.67 (m, 1H; H-4), 4.20-4.15 (m, 3H; H-2'/H-5a/H-5b), 3.96 (m, 1H; H-3'), 3.90 (quint, apparent $J \approx 6.3 \mathrm{~Hz}, 1 \mathrm{H} ; \mathrm{H}-4$ '), 3.26 (dd, $J=13.4,3.3 \mathrm{~Hz}, 1 \mathrm{H} ; \mathrm{CHPh}$ ), 3.20 (br s, $1 \mathrm{H} ; \mathrm{OH}), 2.81(\mathrm{dd}, J=13.4,9.4 \mathrm{~Hz}, 1 \mathrm{H} ; \mathrm{CHPh}), 1.30\left(\mathrm{~d}, J=7 \mathrm{~Hz}, 3 \mathrm{H} ; \mathrm{H}-5\right.$ ' or $M e-\mathrm{C}_{2}$ ), $1.13(\mathrm{~d}$, overlapped, $3 \mathrm{H} ; M e-\mathrm{C}_{2}$, or $\mathrm{H}-5$ '), $1.13 \mathrm{ppm}\left(\mathrm{s}, 9 \mathrm{H} ; \mathrm{Me}_{3} \mathrm{CSi}\right) ;{ }^{13} \mathrm{C} \mathrm{NMR}\left(125 \mathrm{MHz}, \mathrm{CDCl}_{3}\right): \delta=177.4$ (C1'), 152.5 (C2), 135.9 (x 4), 135.1, 134.4, 133.3 (aromatic $\mathrm{C}_{\mathrm{q}}$ ), 129.7, 129.5, 129.4 (x 2), 128.9 (x 2), 127.6 (x 2), 127.4 (x 2), 127.3 (aromatic CH), 75.5 (C3' or C4'), 69.9 (C4'or C3'), 66.0 (C5), 55.0 (C4), 39.0 (C2'), $37.7\left(\mathrm{CH}_{2} \mathrm{Ph}\right), 26.9$ (x 3, Me $\left.\mathrm{CSSi}^{\prime}\right), 19.5\left(\mathrm{C}^{\prime}\right.$ ' or $\mathrm{MeC}_{2}$ ), $19.1\left(\mathrm{C}_{\mathrm{q}}-\mathrm{Si}\right), 11.6 \mathrm{ppm}\left(\mathrm{MeC}_{2}\right.$, or $\left.\mathrm{C}^{\prime}{ }^{\prime}\right)$; IR: $\tilde{v}=3530(\mathrm{br}, \mathrm{OH}), 1787,1678(\mathrm{C}=\mathrm{O}) \mathrm{cm}^{-1}$; HRMS (EI): $m / z$ : calcd for $\mathrm{C}_{32} \mathrm{H}_{39} \mathrm{NO}_{5} \mathrm{Si}-t \mathrm{Bu}$ : 488.1893; 488.1896 ([$\left.\left.M^{+}-t \mathrm{Bu}\right], 38\right), 311(50), 255$ (100), 199 (90), 178 (77); elemental analysis calcd (\%) for $\mathrm{C}_{32} \mathrm{H}_{39} \mathrm{NO}_{5} \mathrm{Si}$ : C 70.43, H 7.20; found: C 70.20, H 7.22.

(S)-4-Benzyl-3-\{(2S,3S,4S)-4-(tert-butyldiphenylsilyloxy)-3-hydroxy-2-methylpentanoyl $\}$ oxazolidin2-one (20): oil; $[\alpha]_{\mathrm{D}}=+14.4\left(c=0.72\right.$ in $\left.\mathrm{CHCl}_{3}\right)$; ${ }^{1} \mathrm{H}$ NMR $\left(500 \mathrm{MHz}, \mathrm{CDCl}^{3}\right): \delta=7.75-7.70(\mathrm{~m}, 4 \mathrm{H}$; aromatic), 7.45-7.20 (br m, 11H; aromatic), 4.50 (m, 1H; H-4), 4.15-4.05 (m, 2H; H-5a/H-5b), 4.00-3.85 (br m, 3H; H-2'/H-3'/H-4'), 3.25 (dd, J=13.3, $3 \mathrm{~Hz}, 1 \mathrm{H} ; \mathrm{CHPh}$ ), 2.75 (dd, J=13.3, $9.5 \mathrm{~Hz}, 1 \mathrm{H} ; \mathrm{CHPh}$ ), $2.70\left(\mathrm{br} \mathrm{d}, J=6.5 \mathrm{~Hz}, 1 \mathrm{H}\right.$; OH), $1.33\left(\mathrm{~d}, J=6.7 \mathrm{~Hz}, 3 \mathrm{H}\right.$; H-5' or $M e-\mathrm{C}_{2}$ ), 1.20 (d, J=6.2 Hz, $3 \mathrm{H} ; M e-\mathrm{C}_{2}$, or H-5'), 1.13 ppm (s, 9H; $\mathrm{Me}_{3} \mathrm{CSi}$ ); ${ }^{13} \mathrm{C}$ NMR (125 MHz, $\left.\mathrm{CDCl}_{3}\right): \delta=175.1(\mathrm{C} 1$ ') $, 152.5(\mathrm{C} 2), 135.7$ (x 4), 135.1, 133.9, 133.0 (aromatic $\mathrm{C}_{\mathrm{q}}$ ), 129.6, 129.5, 129.2 (x 2), 128.7 (x 2), 127.6 (x 2), 127.3 (x 2), 127.1 (aromatic CH), $75.4\left(\mathrm{C}^{\prime}\right.$ ' or C4'), 70.9 (C4' or C3'), $65.8(\mathrm{C} 5), 55.0(\mathrm{C} 4), 40.5\left(\mathrm{C}^{\prime}\right.$ '), $37.5\left(\mathrm{CH}_{2} \mathrm{Ph}\right), 26.9$ (x 3, $\left.\mathrm{Me}_{3} \mathrm{CSi}\right), 20.1\left(\mathrm{C}^{\prime}\right.$ ' or $\mathrm{Me}-\mathrm{C}_{2}$ '), $19.0\left(\mathrm{C}_{\mathrm{q}}-\mathrm{Si}\right), 12.7 \mathrm{ppm}\left(\mathrm{Me}-\mathrm{C} 2{ }^{\prime}\right.$ or $\left.\mathrm{C}-5^{\prime}\right)$; IR: $\tilde{v}=3540(\mathrm{br}, \mathrm{OH})$, 1783, $1694(\mathrm{C}=\mathrm{O}) \mathrm{cm}^{-1}$; HRMS (EI): $\mathrm{m} / z$ : calcd for $\mathrm{C}_{32} \mathrm{H}_{39} \mathrm{NO}_{5} \mathrm{Si}-t \mathrm{Bu}: 488.1893$; $488.1897\left(\left[M^{+}-t \mathrm{Bu}\right]\right.$, 24), 255 (55), 199 (100), 178 (51); elemental analysis calcd (\%) for $\mathrm{C}_{32} \mathrm{H}_{39} \mathrm{NO}_{5} \mathrm{Si}$ : C 70.43, $\mathrm{H}$ 7.20; found: C 70.52, H 7.37 .

(S)-4-Benzyl-3-\{(2S,3S,4R)-4-fluoro-3-hydroxy-2-methyl-5-phenylpentanoyl\}oxazolidin-2-one (21): oil; $[\alpha]_{\mathrm{D}}=+52.2\left(c=1.8\right.$ in $\left.\mathrm{CHCl}_{3}\right) ;{ }^{1} \mathrm{H}$ NMR (500 MHz, $\left.\mathrm{CDCl}_{3}\right): \delta=7.35-7.20$ (br m, 10H; aromatic), 
$4.66(\mathrm{~m}, 1 \mathrm{H} ; \mathrm{H}-4), 4.62$ (dtd partially overlapped by the signal at $\delta 4.66,{ }^{2} J_{\mathrm{H}, \mathrm{F}}=47.5 \mathrm{~Hz}, J=7.6,3 \mathrm{~Hz}$, 1H; H-4'), 4.20-4.15 (m, 2H; H-5a/H-5b), 4.00 (m, 2H; H- 2'/H-3'), 3.30-3.20 (m, 2H; H-5' a/CHPh), $2.98\left(\mathrm{ddd},{ }^{3} J_{\mathrm{H}, \mathrm{F}}=26 \mathrm{~Hz}, J=15,7.3 \mathrm{~Hz}, 1 \mathrm{H} ; \mathrm{H}-5\right.$ 'b), $2.80(\mathrm{dd}, J=13.5,9.5 \mathrm{~Hz}, 1 \mathrm{H} ; \mathrm{CHPh}), 1.35 \mathrm{ppm}(\mathrm{d}$, $\left.J=7 \mathrm{~Hz}, 3 \mathrm{H} ; M e-\mathrm{C}_{2}\right)$ ); ${ }^{13} \mathrm{C}$ NMR $\left(125 \mathrm{MHz}, \mathrm{CDCl}_{3}\right): \delta=177.5(\mathrm{C} 1$ '), $152.6(\mathrm{C} 2), 136.9,135.0$ (aromatic $\mathrm{C}_{\mathrm{q}}$ ), 129.8 (x 2), 129.4 (x 2), 129.0 (x 2), 128.3 (x 2), 127.5, 126.6 (aromatic CH), 93.0/91.7 (C4', d, ${ }^{1} J_{\mathrm{C}, \mathrm{F}}$ $\approx 172.5 \mathrm{~Hz}), 71.5 / 71.3\left(\mathrm{C} 3{ }^{\prime}, \mathrm{d},{ }^{2} J_{\mathrm{C}, \mathrm{F}} \approx 25.3 \mathrm{~Hz}\right), 66.2(\mathrm{C} 5), 55.0(\mathrm{C} 4), 38.7\left(\mathrm{C} 2\right.$ '), $37.9 / 37.8\left(\mathrm{C} 5{ }^{\prime}, \mathrm{d},{ }^{2} J_{\mathrm{C}, \mathrm{F}} \approx\right.$ $15.5 \mathrm{~Hz}), 37.8\left(\mathrm{CH}_{2} \mathrm{Ph}\right), 11.0 \mathrm{ppm}\left(\mathrm{Me}-\mathrm{C}_{2}\right) ;{ }^{19} \mathrm{~F} \mathrm{NMR} \delta=-190.8 \mathrm{ppm}(\mathrm{dt}, J \approx 47.5, \approx 26 \mathrm{~Hz})$; IR: $\tilde{v}$ $=3500(\mathrm{br}, \mathrm{OH}), 1781,1690(\mathrm{C}=\mathrm{O}) \mathrm{cm}^{-1}$; HRMS (FAB): $m / z$ : calcd for $\mathrm{C}_{22} \mathrm{H}_{25} \mathrm{FNO}_{4}: 386.1767$ [M+H $\left.{ }^{+}\right]$; found: 386.1773; elemental analysis calcd (\%) for $\mathrm{C}_{22} \mathrm{H}_{24} \mathrm{FNO}_{4}$ : C 68.56, H 6.28; found: C 68.52, H 6.39.

\section{Acknowledgements}

Financial support has been granted by the Spanish Ministry of Education and Science (projects CTQ2005-06688-C02-01 and CTQ2005-06688-C02-02) and by the Fundació Caixa CastellóUniversitat Jaume I (projects PI-IB-2005-30 and PI-IA-2005-15). S. D.-O. thanks the University Jaume I for a postdoctoral contract. The authors further thank X. Fontrodona, from the Serveis Técnics de Recerca, University of Girona, and G. Peris, from the Serveis Centrals de Instrumentació of the University Jaume I, for their collaboration in some X-ray diffraction analyses.

\footnotetext{
${ }^{1}$ a) D. A. Evans, J.V. Nelson, T. R. Taber, Top. Stereochem. 1982, 13, 1- 115; b) T. Mukaiyama, Org. React. 1982, 28, 203 - 331; c) S. Masamune, W. Choy, J. S. Petersen, L. R. Sita, Angew. Chem. 1985, 97, 1-31; Angew. Chem. Int. Ed. Engl. 1985, 24, 1 -30; d) C. H. Heathcock, in Asymmetric Synthesis, Vol. 3 (Ed.: J. D. Morrison), Academic Press, Orlando, 1984, pp. 111 -212; e) C. H. Heathcock, Aldrichimica Acta 1990, 23, 99-111; f) Comprehensive Organic Synthesis, Vol. 2 (Eds.: B. M. Trost, I. Fleming, E. Winterfeldt), Pergamon Press, Oxford, 1993; g) H. B. Mekelburger, C. S. Wilcox in Comprehensive Organic Synthesis, Vol. 2 (Eds.: B. M. Trost, I. Fleming, E. Winterfeldt), Pergamon Press, Oxford, 1993, pp. $99-131$; h) C. H. Heathcock in Comprehensive Organic Synthesis, Vol. 2 (Eds.: B. M. Trost, I. Fleming, E. Winterfeldt), Pergamon Press, Oxford, 1993, pp. 133 -179 and 181 238; i) B. M. Kim, S. F. Williams, S. Masamune in Comprehensive Organic Synthesis, Vol. 2 (Eds.: B. M. Trost, I. Fleming, E. Winterfeldt), Pergamon Press, Oxford, 1993, pp. 239 - 275; j) M. W. Rathke, P. Weipert in Comprehensive Organic Synthesis, Vol. 2 (Eds.: B. M. Trost, I. Fleming, E. Winterfeldt), Pergamon Press, Oxford, 1993, pp. 277 -299; k) I. Paterson in Comprehensive Organic Synthesis, Vol. 2 (Eds.: B. M. Trost, I. Fleming, E. Winterfeldt), Pergamon Press, Oxford, 1993, pp. 301 - 319; 1) A. S. Franklin, I. Paterson, Contemp. Org. Synth. 1994, 1, 317 - 338; m) M. Braun, in Houben-Weyl's Methods of Organic Chemistry, Stereoselective Synthesis, Vol. 3, (Eds.: G. Helmchen, R. W. Hoffmann, J. Mulzer, E. Schaumann), Thieme, Stuttgart, 1996, pp. 1603 -1666 and $1713-1735 ;$ n) R. Mahrwald, Chem. Rev. 1999, 99, $1095-1120$; o) C. Palomo, M. Oiarbide, J. M. Garc1a, Chem. Eur. J. 2002, 8, 36- 44; p) C. Palomo, M. Oiarbide, J. M. Garc1a, Chem. Soc. Rev. 2004, 33, 65- 75; q) Modern Aldol Reactions (Ed.: R. Mahrwald), Wiley-VCH, Weinheim, 2004; r) E. M. Carreira, A. Fettes, C. Marti, Org. React. 2006, 67, 1- 216; s) D. A. Evans, G. Helmchen, M. Ruping, J. Wolfgang, in Asymmetric Synthesis, (Eds.: M. Christmann, S. Bräse), Wiley-VCH, Weinheim, 2007, pp. 3-9.

2 a) C. J. Cowden, I. Paterson, Org. React. 1997, 51, 1- 200; b) A. Abiko, Acc. Chem. Res. 2004, 37, 387 -395.

3 a) M. Carda, J. Murga, E. Falomir, F. Gonz8lez, J.A. Marco, Tetrahedron 2000, 56, 677 - 683; b) J. Murga, E. Falomir, M. Carda, J.A. Marco, Tetrahedron: Asymmetry 2002, 13, 2317 -2327; c) J. Murga, E. Falomir, F. González, M. Carda, J.A. Marco, Tetrahedron 2002, 58, 9697 - 9707; d) See also: J. Murga, E. Falomir, M. Carda, F. Gonzalez, J.A. Marco, Org. Lett. 2001, 3, 901 904.

${ }^{4}$ Other ketones structurally related to erythrulose behave in the same way: a) M. Carda, J. Murga, E. Falomir, F. Gonzalez, J.A. Marco, Tetrahedron: Asymmetry 2000, 11, 3211 -3220; b) M. Carda, F. González, R. Sánchez, J.A. Marco, Tetrahedron: Asymmetry 2002, 13, $1005-1010$.

5 J.A. Marco, M. Carda, Díaz-Oltra, S. J. Murga, E. Falomir, H. Roeper, J. Org. Chem. 2003, 68, 8577 - 8582.

${ }^{6}$ H. E. Zimmerman, M. D. Traxler, J. Am. Chem. Soc. 1957, 79, 1920 -1923.

${ }^{7}$ For theoretical studies on boron aldol reactions, see: a) Y. Li, M. N. Paddon-Row, K. N. Houk, J. Org. Chem. 1990, 55, 481 -493; b) J. M. Goodman, S. D. Kahn, I. Paterson, J. Org. Chem. 1990, 55, 3295 - 3303; c) A. Bernardi, A. M. Capelli, C. Gennari, J. M. Goodman, I. Paterson, J. Org. Chem. 1990, 55, 3576 -3581; d) A. Bernardi, A. M. Capelli, A. Comotti, C. Gennari, M. Gardner, J. M. Goodman, I. Paterson, Tetrahedron 1991, 47, 3471 - 3484; e) F. Bernardi, M.A. Robb, G. Suzzi-Valli, E. Tagliavini, C. Trombini, A. Umani-Ronchi, J. Org. Chem. 1991, 56, 6472 -6475; f) C. Gennari, S. Vieth, A. Comotti, A. Vulpetti, J. M. Goodman, I. Paterson, Tetrahedron 1992, 48, 4439 - 4458; g) A. Vulpetti, A. Bernardi, C. Gennari, J. M. Goodman, I. Paterson, Tetrahedron 1993, 49, 685 - 696; h) V. J. Cee, C. J. Cramer, D. A. Evans, J. Am. Chem. Soc. 2006, 128, 2920 - 2930.

${ }^{8}$ N. A. Van Draanen, S. Arseniyadis, M. T. Crimmins, C. H. Heathcock, J. Org. Chem. 1991, 56, 2499 - 2506. For another example which shows the importance of dipole alignment in aldol transition states, see: R. K. Boeckman Jr. , B. T. Connell, J. Am. Chem. Soc. $1995,117,12368-12369$.

${ }^{9}$ W. R. Roush, J. Org. Chem. 1991, 56, $4151-4157$. The quantitative importance of the syn-pentane interactions is underscored in our cases by the fact that enolate $1_{\mathrm{B}}$ does not react with pivalaldehyde, see ref. [3]. Indeed, if a TS is drawn for the aldol reaction with this aldehyde, a steric interaction of the aforementioned type will always be present for all rotamers around the $t \mathrm{Bu}-\mathrm{CO}$ bond. ${ }^{10}$ The various factors which may influence the stereochemical outcome of aldol reactions have been analyzed in detail by Danishefsky and co-workers: C.B. Lee, Z. Wu, F. Zhang, M.d. Chappell, S.J. Stachel, T.-C. Chou, Y. Guan, S.J. Danishhefsky, j. Am. Chem. Soc. 2001, 123, 5249-5259.
} 
${ }^{11}$ In all discussions in this paper, no specific differentiation has been made between the purely steric Felkin-Anh model (for aldehydes containing all-carbon substituents) and the stereoelectronic "polar Felkin-Anh" model (for aldehydes containing $\alpha$ heteroatoms): a) M. ChYrest, H. Felkin, N. Prudent, Tetrahedron Lett. 1968, 9, 2199 - 2204; b) N. T. Anh, Top. Curr. Chem. 1980, 88, 145 - 162; c) A. Mengel, O. Reiser, Chem. Rev. 1999, 99, 1191 - 1223. See also: R. J. Smith, M. Trzoss, M. Bühl, S. Bienz, Eur. J. Org. Chem. 2002, $2770-2775$.

12 a) H. B. Bürgi, J. D. Dunitz, E. Shefter, J. Am. Chem. Soc. 1973, 95, 5065 - 5067; b) H. B. Bürgi, J. D. Dunitz, J. M. Lehn, G. Wipff, Tetrahedron 1974, 30, $1563-1572$; c) R. E. Gawley, J. AubY, Principles of Asymmetric Synthesis, Pergamon, 1996, Chapters 4 and 5.

${ }^{13}$ E. P. Lodge, C. H. Heathcock, J. Am. Chem. Soc. 1987, 109, 3353 - 3361. The "non-Anh" label refers to transition structures in which attack takes place anti to a substituent which neither has the lowest lying $\sigma^{*} \mathrm{C}$-X orbital (for $\alpha$-heteroatom-substituted aldehydes) nor is the sterically bulkiest one (for aldehydes not containing $\alpha$-heteroatoms). See also ref. [12 c].

${ }^{14}$ a) J. W. Cornforth, R. H. Cornforth, K.K. Mathew, J. Chem. Soc.1959, 112 - 127; for theoretical refinements of the model, see: b) M. N. Paddon-Row, N. G. Rondan, K. N. Houk, J. Am. Chem. Soc. 1982, 104, 7162 - 7166; c) K. N. Houk, M. N. Paddon-Row, N. G. Rondan, Y.-D. Wu, F. K. Brown, D. C. Spellmeyer, J. T. Metz, Y. Li, R. J. Longarich, Science 1986, 231,1108 -1117.

${ }^{15}$ Cornforth's model has been previously applied to reactions of $\alpha$-oxygenated aldehydes with achiral allylboron compounds: a) W. R. Roush, M.A. Adam, A. E. Walts, D. J. Harris, J. Am. Chem. Soc. 1986, 108, 3422 -3434; b) H. Brinkmann, R. W. Hoffmann, Chem. Ber. 1990, 123, 2395 - 2401; c) A. N. Thadani, R. A. Batey, Tetrahedron Lett. 2003, 44, 8051 -8055; d) The higher stability of Cornforthlike transition structures in some additions of allylboron reagents to $\alpha$-oxygenated aldehydes has also received theoretical support: B. W.Gung, X. Xue, Tetrahedron: Asymmetry 2001, 12, 2955 -2959; e) For more detailed accounts of the diastereoselective reactions of allylboron compounds, see: W. R. Roush in Comprehensive Organic Synthesis, Vol. 2 (Eds.: B. M. Trost, I. Fleming, E. Winterfeldt), Pergamon Press, Oxford, 1993 pp. 1 -54, and: W. R. Roush, in Houben-Weyl's Methods of Organic Chemistry, Stereoselective Synthesis, Vol. 3 (Eds: G. Helmchen, R. W. Hoffmann, J. Mulzer, E. Schaumann), Thieme, Stuttgart, 1996, pp. $1410-1486$, and references therein; f) for a related situation in the addition of an allenylstannane, see: J.A. Marshall, X.-J. Wang, J. Org. Chem. 1991, 56, 3211 -3213.

${ }^{16}$ When we were performing our investigations with ketone 1, a paper by Evans and co-workers appeared in which the modified Cornforth model was applied to provide a good explanation of the sterochemical outcome of aldol reactions of achiral ketones with $\alpha$-heteroatom-substituted aldehydes: D.A. Evans, S.J. Siska, V.J. Cee, Angew. Chem. 2003, 115, 1803-1807; Angew. Chem. Int. Ed. 2003, 42, 1761-1765.

${ }^{17}$ Stereoselective aldol reactions with $\alpha$-fluoro aldehydes (excluding $\alpha, \alpha$-difluoro aldehydes) are almost unknown. We have found only two reports in the bibliography, both of them referring to chiral afluoro- $\alpha$-methylaldehydes. One is the reaction of such aldehydes with achiral enolsilanes under Lewis acid catalysis: T. Yamazaki, T. Yamamoto, T. Kitazume, J. Org. Chem. 1989, 54, 83-91. The reactions give, however, very variable yields and show, in general, a medium-to-low stereoselectivity. They are assumed to take place through open transition states, either chelated or unchelated. The other report describes low-yielding reactions with the boron enolate of a chiral $\alpha$-acyloxy ketone: S. L. Less, P. F. Leadlay, C. J. Dutton, J. Staunton, Tetrahedron Lett. 1996, $37,3519-$ 3520 .

${ }^{18}$ For nucleophilic additions to aldehydes containing other types of aheteroatoms, see, for example: a) D. Enders, O. Piva, F. Burkamp, Tetrahedron 1996, 52, 2893 -2908 ( $\alpha$-sulphenyl aldehydes); b) D. Enders, J. Adam, D. Klein, T. Otten, Synlett 2000, 1371 - 1384 (asilyl aldehydes); see also: D. Enders, F. Burkamp, Collect. Czech. Chem. Commun. 2003, 68, 975 -1006.

${ }^{19}$ Details of the preparation of aldehydes $8 \mathrm{a}, \mathrm{b}$ and $9 \mathrm{a}-\mathrm{c}$ as well as of the structural elucidation of the new aldols are given in the Supporting Information.

${ }^{20}$ We did not deem it necessary to extend the study of $18_{\mathrm{B}}$ to $\alpha$-amino aldehydes or to aldehydes having all-carbon $\alpha$-substituents, as it has been established that aldol reactions of boron enolates of Evans oxazolidinones with such aldehydes are stereocontrolled in almost all cases by the chiral enolate. See refs. [1 and 2] and also: a) K. Hayashi, Y. Hamada, T. Shioiri, Tetrahedron Lett. 1991, 32, 7287 -7290; b) T. Owa, H. Haupt, M. Otsuka, S. Kobayashi, N. Tomioka, A. Itai, M. Ohno, T. Shiraki, M. Uesugi, Y. Sugiura, K. Maeda, Tetrahedron 1992, 48, 1193 - 1208; c) T. Shioiri, K. Hayashi, Y. Hamada, Tetrahedron 1993, 49, 1913 - 1924; d) D. L. Boger, S. L. Colletti, T. Honda, R. F. Menezes, J. Am. Chem. Soc. 1994, 116, 5607 -5618; e) G. R. Pettit, D. D. Burkett, J. Bark=czy, G. L. Breneman, W. E. Pettit, Synthesis 1996, 719 - 725; f) M. J. Rishel, S. M. Hecht, Org. Lett. 2001, 3, 2867 - 2869; g) A. N. Hulme, C. H. Montgomery, Tetrahedron Lett. 2003, 44, 7649 - 7653; h) E. M. Rosser, S. Morton, K. S. Ashton, P. Cohen, A. N. Hulme, Org. Biomol. Chem. 2004, 2, $142-149$.

${ }^{21}$ Aldol reactions of boron enolates of Evans oxazolidinones with aoxygenated aldehydes also are often stereocontrolled by the chiral enolate. However, at least one case is known where the strong Felkin stereofacial bias of the aldehyde overcame that of a chiral $\mathrm{N}$-acyloxazolidinone and forced the formation of an anti aldol from the (Z)-boron enolate: D. A. Evans, S. W. Kaldor, T. K. Jones, J. Clardy, T. J. Stout, J. Am. Chem. Soc. 1990, 112, $7001-7031$.

22 J. Murga, E. Falomir, M. Carda, J.A. Marco, Tetrahedron 2001, 57, 6239 - 6247, and references therein.

${ }^{23}$ M. J. Frisch, G. W. Trucks, H. B. Schlegel, G. E. Scuseris, M.A. Robb, J. R. Cheeseman, V. G. Zakrezewski, J.A. Montgomery, R. E. Stratmann, J. C. Burant, S. Dapprich, J. M. Millam, A. D. Daniels, K. N. Kudin, M. C. Strain, O. Farkas, J. Tomasi, V. Barone, M. Cossi, R. Cammi, B. Mennucci, C. Pomelli, C. Adamo, S. Clifford, J. Ochterski, G. A. Peterson, P. Y. Ayala, Q. Cui, K. Morokuma, D. K. Malick, A. D. Rabuck, K. Raghavachari, J. B. Foresman, J. Cioslowski, J.V. Ortiz, B. B. Stefanov, G. Liu, A. Liashenko, P. Piskorz, R. Komaromi, R. Gomperts, R. L. Martin, D. J. Fox, T. Keith, M. A. Al-Laham, C. Y. Peng, A. Nanayakkara, C. González, M. Challacombe, P. M. W. Gill, B. G. Johnson, W. Chen, M. W. Wong, J. L. Andrés, M. Head-Gordon, E. S. Replogle, J.A. Pople, Gaussian 98 (Revision A.1); Gaussian, Inc., Pittsburgh, PA, 1998.

${ }^{24}$ a) A. D. Becke, Phys. Rev. A 1988, 38, 3098 -3100; b) C. Lee, W. Yang, R. G. Parr, Phys. Rev. B 1988, 37, 785 - 789; c) A. D. Becke, J. Chem. Phys. 1993, 98, $5648-5652$; d) P. J. Stephens, F. J. Devlin, C. F. Chabalowski, M. J. Frisch, J. Phys. Chem. 1994, $98,11623-11627$.

${ }^{25}$ W. J. Hehre, L. Radom, P. von R. Schleyer, J. A. Pople, Ab Initio Molecular Orbital Theory, Wiley, New York, 1986.

${ }^{26}$ The angles $\varphi_{1}$ and $\varphi_{2}$ are not defined here in the same manner as in reference [7h].

${ }^{27}$ For most transition structures described here, the calculated angle of attack of the nucleophile to the carbonyl group lies in the range $97-100^{\circ}$. Notable exceptions were found in some transition states with fluorinated aldehydes, where the calculated angles were markedly smaller $\left(<95^{\circ}\right)$.

${ }^{28}$ The solvent may impart some additional stability to synperiplanar conformations $\left(\varphi_{2}=0\right)$ of $\alpha$-oxygenated aldehydes, see: B. Lecea, A.Arrieta, F. P. Coss1o, J. Org. Chem. 1997, 62, 6485-6492, and references therein.

${ }^{29}$ After these results were obtained, the calculations were repeated for $\alpha$-alkoxy aldehydes $(R)$ - and $(S)$-23b and a model ketone enolate 1 , closer to the actual reagent 1 . However, the results were essentially the same as with 22 and therefore the calculations were not continued with the other aldehydes. 
${ }^{30}$ a) M. J. S. Dewar, J. Kelemen, J. Chem. Phys. 1968, 49, 499 -508; b) K. Kushida, A. Watanabe, Proton and Fluorine Magnetic Resonance Spectral Data, 1988, Japan Halon Co. Ltd., Tokyo, 1988. 